CRYSTALLOGRAPHIC COMMUNICATIONS

ISSN 2056-9890

Received 1 January 2020

Accepted 10 January 2020

Edited by M. Zeller, Purdue University, USA

Keywords: crystal structure; hydrogen bonding quinoline; carboxamide; amine.

CCDC reference: 1879928

Supporting information: this article has supporting information at journals.iucr.org/e

\section{The synthesis, crystal structure and Hirshfeld analysis of 4-(3,4-dimethylanilino)- $\mathrm{N}$-(3,4-di- methylphenyl)quinoline-3-carboxamide}

\author{
Ligia R. Gomes, ${ }^{\text {a,b }}$ John Nicolson Low, ${ }^{\text {c* Fernanda Borges, }}{ }^{\text {d Alexandra Gaspard }}{ }^{\text {and }}$ \\ Francesco Mesiti
}

aREQUIMTE, Departamento de Química e Bioquímica, Faculdade de Ciências da Universidade do Porto, Rua do Campo Alegre, 687, P-4169-007, Porto, Portugal, 'b FP-ENAS-Faculdade de Ciências de Saúde, Escola Superior de Saúde da UFP, Universidade Fernando Pessoa, Rua Carlos da Maia, 296, P-4200-150 Porto, Portugal, 'Department of Chemistry, University of Aberdeen, Meston Walk, Old Aberdeen, AB24 3UE, Scotland, ${ }^{\mathbf{d} C I Q U P}$ Departamento de Quımica e Bioquımica, Faculdade de Ciências, Universidade do Porto, 4169-007 Porto, Portugal, and ${ }^{\mathbf{e}}$ Department of "Scienze della Vita", University "Magna Graecia" of Catanzaro, Catanzaro, Italy. *Correspondence e-mail: jnlow111@gmail.com

The structure of the title quinoline carboxamide derivative, $\mathrm{C}_{26} \mathrm{H}_{25} \mathrm{~N}_{3} \mathrm{O}$, is described. The quinoline moiety is not planar as a result of a slight puckering of the pyridine ring. The secondary amine has a slightly pyramidal geometry, certainly not planar. Both intra- and intermolecular hydrogen bonds are present. Hirshfeld surface analysis and lattice energies were used to investigate the intermolecular interactions.

\section{Chemical context}

Quinoline (1-aza-naphthalene or benzo[b]pyridine) is a natural heterocyclic building block often used as a template for derivatization and generation of drug-like libraries for the discovery of novel bioactive ligands (Mugnaini et al., 2009; Musiol, 2017). Quinoline-based compounds are well known for their antimalarial activity (Antony \& Parija, 2016), although a large spectrum of other biological activities, such as anticancer, antimicrobial, anti-inflammatory, antioxidant, antihypertensive and against neurodegenerative diseases, have also been ascribed to these types of heterocyclic compounds (Nainwal et al., 2019).

This work is a continuation of our investigation into the preparation, structural analysis and pharmacological properties of substituted heterocyclics including, for example, new insights in the discovery of novel h-MAO-B inhibitors obtained by the structural characterization of a series of $\mathrm{N}$-phenyl-4-oxo-4H-chromene-3-carboxamide derivatives (Gomes et al., 2015a). Other chromone and coumarin carboxamides are discussed in Gomes et al. $(2015 b, 2016)$.

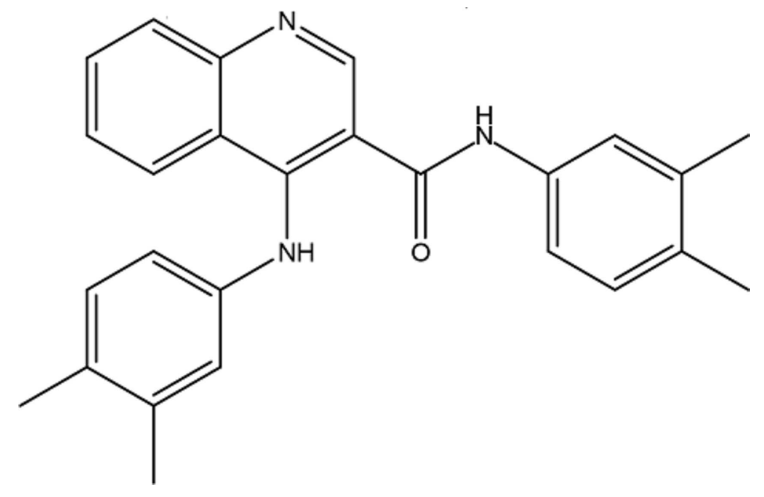




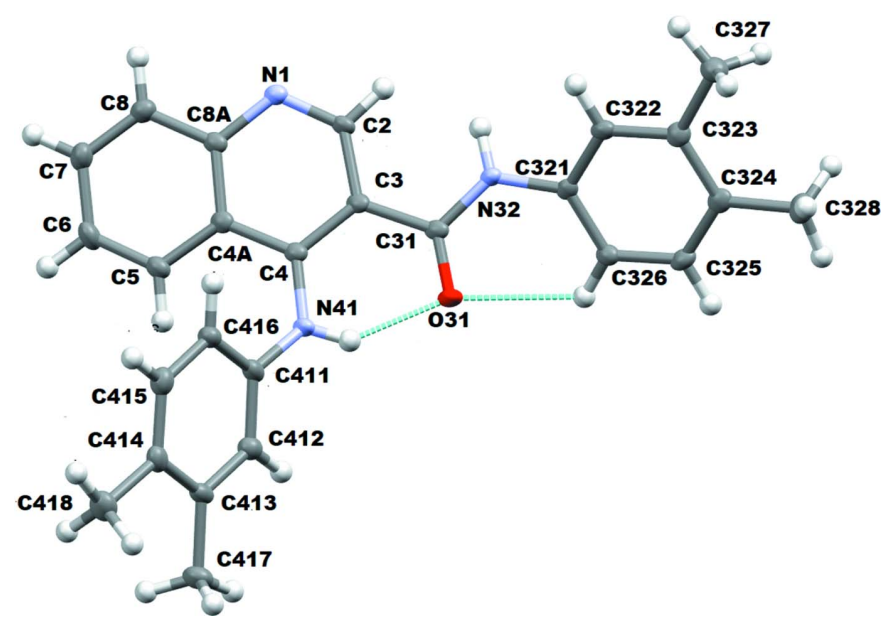

Figure 1

A view of the asymmetric unit of $\mathbf{1}$ with the atom-numbering scheme. Displacement ellipsoids are drawn at the $50 \%$ probability level.

Here we report the synthesis and structural characterization of a quinoline-3-carboxamide derivative, 4-(3,4-dimethylanilino)- $N$-(3,4-dimethylphenyl)quinoline-3-carboxamide, $\mathbf{1}$.

\section{Structural commentary}

An ellipsoid plot for compound $\mathbf{1}$ is shown in Fig. 1. The quinoline ring system is not planar, with atoms $\mathrm{C} 2$ and $\mathrm{C} 4$ deviating from the mean plane of the quinoline ring by -0.110 (3) and 0.125 (3) A, respectively, and C6 lying -0.100 (3) $\AA$ below the mean plane. The pyridine ring is slightly puckered with a screw-boat conformation, $Q=$ $0.087(3) \AA, \theta=106(2)^{\circ}$ and $\varphi=25(2)^{\circ}$. The mean plane of this ring makes a dihedral angle of $7.49(13)^{\circ}$ with the mean plane of the benzene ring of the quinoline moiety. The angles between the mean planes of the quinoline ring and the benzene rings with pivot atoms C321 and C411 are 28.99 (11) and $59.16(11)^{\circ}$ respectively. The dihedral angle between the mean plane of these benzene rings is $64.71(14)^{\circ}$.

The amide group attached to $\mathrm{C} 3$ is coplanar with the quinoline ring system. The $\mathrm{C}-\mathrm{N}$ rotamer of the amide has an anti conformation placing the quinoline ring trans in relation to the ring with pivot atom C321. The amide group atoms are essentially coplanar with the quinoline ring with deviations of -0.034 (3), (C31), -0.009 (2) (O31), 0.009 (2), (N32) and 0.145 (3) $\AA$ (C321). The geometric arrangement of the amide permits the formation of an intramolecular hydrogen bond between the amine hydrogen atom and the carboxyl group of the amide, $\mathrm{N} 41-\mathrm{H} 41 \cdots \mathrm{O} 31$; geometric parameters are given in Table 1. A further intramolecular hydrogen bond, C326H326.. O31, occurs.

The secondary amine has a slightly pyramidal geometry, certainly not planar. The angles C411-N41-C4, C41-N41H41 and C411-N41-H41 are 125.7 (2), 112 (2) and 115 (2) ${ }^{\circ}$, respectively, the sum of which $\left(352.7^{\circ}\right)$ is less than $360^{\circ}$; in addition, atom $\mathrm{H} 41$ lies 0.41 (3) $\AA$ out of the $\mathrm{C} 4 / \mathrm{N} 41 / \mathrm{C} 411$ mean plane, confirming the $s p^{3}$ hybridization of N41. An inspection of the amine bond lengths shows that there is a
Table 1

Hydrogen-bond geometry $\left(\AA,^{\circ}\right)$.

$C g$ is the centroid of the $\mathrm{N} 1 / \mathrm{C} 2-\mathrm{C} 4 / \mathrm{C} 4 A / \mathrm{C} 8 A$ ring.

\begin{tabular}{lllll}
\hline$D-\mathrm{H} \cdots A$ & $D-\mathrm{H}$ & $\mathrm{H} \cdots A$ & $D \cdots A$ & $D-\mathrm{H} \cdots A$ \\
\hline $\mathrm{N} 41-\mathrm{H} 41 \cdots \mathrm{O} 31$ & $0.84(4)$ & $1.93(3)$ & $2.635(3)$ & $142(3)$ \\
$\mathrm{C} 326-\mathrm{H} 326 \cdots \mathrm{O} 31$ & 0.95 & 2.40 & $2.887(3)$ & 112 \\
$\mathrm{~N} 32-\mathrm{H} 32 \cdots \mathrm{N} 1^{\mathrm{i}}$ & $0.90(4)$ & $2.07(4)$ & $2.891(3)$ & $150(3)$ \\
$\mathrm{C} 2-\mathrm{H} 2 \cdots \mathrm{N} 1^{\mathrm{i}}$ & $0.96(3)$ & $2.55(3)$ & $3.477(4)$ & $163(2)$ \\
$\mathrm{C} 416-\mathrm{H} 416 \cdots \mathrm{O} 31^{\mathrm{ii}}$ & 0.95 & 2.39 & $3.252(4)$ & 150 \\
$\mathrm{C} 326-\mathrm{H} 326 \cdots C g^{\mathrm{iii}}$ & 0.95 & 2.82 & $3.398(3)$ & 120 \\
\hline
\end{tabular}

Symmetry codes: (i) $x+\frac{1}{2},-y+\frac{3}{2},-z+1$; (ii) $x-1, y, z$; (iii) $x+1, y, z$.

slight asymmetry of the electronic distribution around it: C4-

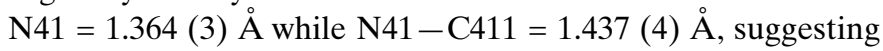
there is higher density between the nitrogen and the carbon atom of the quinoline ring system. However, these bonds and angles are typical for a $\mathrm{C}_{\text {quinoline }}-\mathrm{NH}-\mathrm{C}-\mathrm{R}$ group, see the Database Survey below. As a consequence of the screw-boat pucker of the pyridine ring, the $\mathrm{C} 4-\mathrm{N} 41$ bond is displaced from the pyridine mean plane with a deviation of 0.159 (2) $\AA$ for N41; atom C411 is displaced by 0.965 (3) $\AA$ and consequently, the $\mathrm{N} 41-\mathrm{C} 411$ bond lies further from the mean plane.

\section{Supramolecular features}

In the crystal, the molecules are linked by N32$\mathrm{H} 32 \cdots \mathrm{N} 1\left(x+\frac{1}{2},-y+\frac{3}{2},-z+1\right)$, hydrogen bonds, forming $C 6$ chains which run parallel to the $a$-axis formed by the action of the $2_{1}$ screw axis at $\left(\frac{1}{2}, 0, \frac{3}{4}\right)$. This is supplemented by the weak $\mathrm{C} 2-\mathrm{H} 2 \cdots \mathrm{N} 1\left(x+\frac{1}{2},-y+\frac{3}{2},-z+1\right)$ hydrogen bond, Table 1 and Fig. 2. The other weak hydrogen bonds, C416-

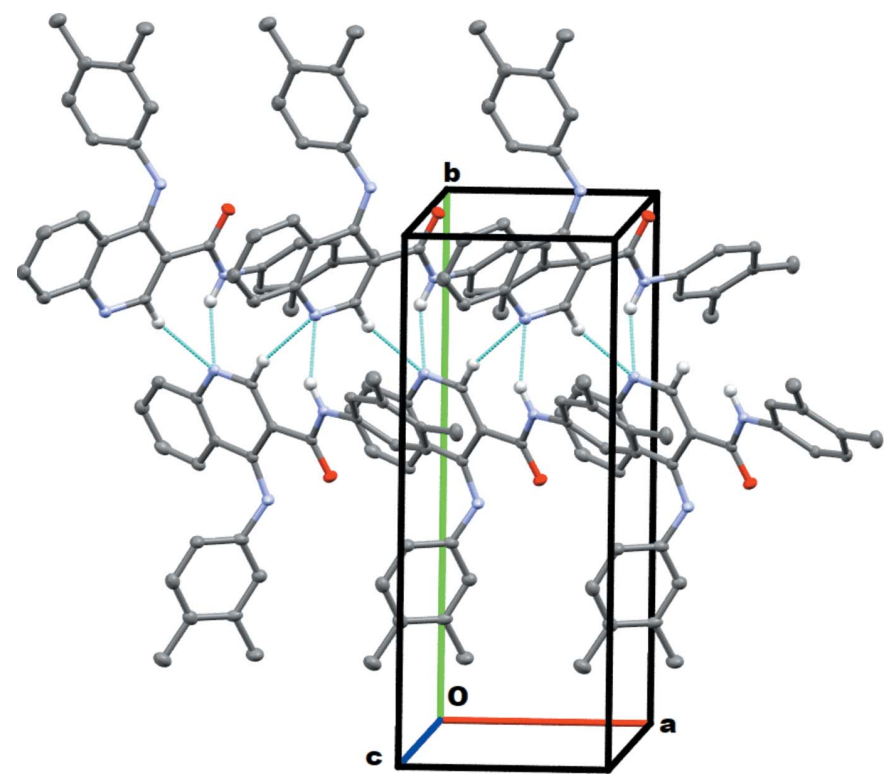

Figure 2

A view of the $\mathrm{N} 32-\mathrm{H} 32 \cdots \mathrm{N} 1 \mathrm{C} 6$ chain running along the $a$ axis with the supplementary $\mathrm{C} 2-\mathrm{H} 2 \cdots \mathrm{N} 1$ bond. Hydrogen atoms not involved in the hydrogen bonding are omitted for clarity. 


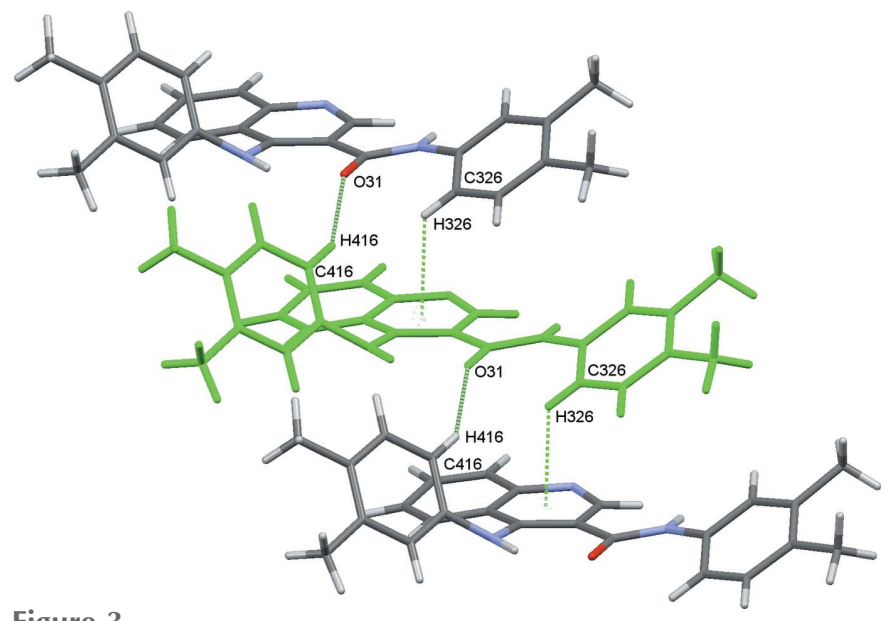

Figure 3

Molecule pairs Ia/Ib: $x-1, y, z$ (top) and $x+1, y, z$ (bottom). Values of energies by pair: $E_{\mathrm{tot}}=-55.9 \mathrm{~kJ} \mathrm{~mol}^{-1}, E_{\text {coul }}=-21.4 \mathrm{~kJ} \mathrm{~mol}^{-1}, E_{\mathrm{pol}}=$ $-10.0 \mathrm{~kJ} \mathrm{~mol}^{-1}, E_{\mathrm{disp}}=-79.5 \mathrm{~kJ} \mathrm{~mol}^{-1}$ and $E_{\text {rep }}=55.0 \mathrm{~kJ} \mathrm{~mol}^{-1}$. Interaction energies were calculated using PIXEL3.1 (Gavezzotti, 2003, 2008) based on densities computed with G09 using the mp2/6-31** level of theory.

$\mathrm{H} 416$. . O31 and $\mathrm{C} 418-\mathrm{H} 41 B \cdots \mathrm{O} 31$, both involve atom $\mathrm{O} 31$ as an acceptor and link the chains described above to form a sheet which extends along the $b$-axis direction.

No $\pi-\pi$ interactions occur but there is a possible $\mathrm{C}-\mathrm{H} \cdots \pi$ interaction, $\mathrm{C} 326-\mathrm{H} 326 \cdots \mathrm{Cg}$, involving the pyridine ring (Table 1), which is discussed more fully below.

\section{Hirshfeld surface analysis and lattice energies}

Hirshfeld surfaces (McKinnon et al., 2004) and two-dimensional fingerprint (FP) plots provide complementary information concerning the intermolecular interactions discussed

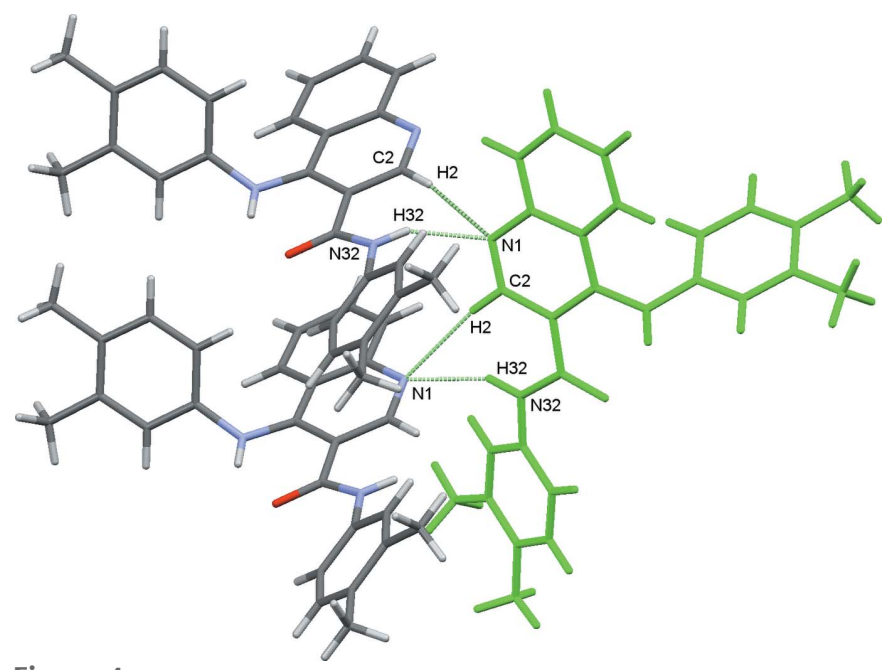

Figure 4

Molecule pairs IIa/IIb: $x-\frac{1}{2},-y+\frac{3}{2},-z+1$ (top) and $x-\frac{1}{2},-y+\frac{3}{2},-z+\frac{1}{2}$, $-y+\frac{3}{2},-z+1$ (bottom). Values of energies by pair: $E_{\mathrm{tot}}=-52.3$ $0 \mathrm{~kJ} \mathrm{~mol}^{-1}, E_{\text {coul }}=-59.10 \mathrm{~kJ} \mathrm{~mol}^{-1}, E_{\mathrm{pol}}=-26.90 \mathrm{~kJ} \mathrm{~mol}^{-1}, E_{\text {disp }}=$ $-41.50 \mathrm{~kJ} \mathrm{~mol}^{-1}$ and $E_{\text {rep }}=75.20 \mathrm{~kJ} \mathrm{~mol}^{-1}$. Interaction energies were calculated using PIXEL3.1 (Gavezzotti, 2003, 2008) based on densities computed with G09 using the mp2/6-31** level of theory.

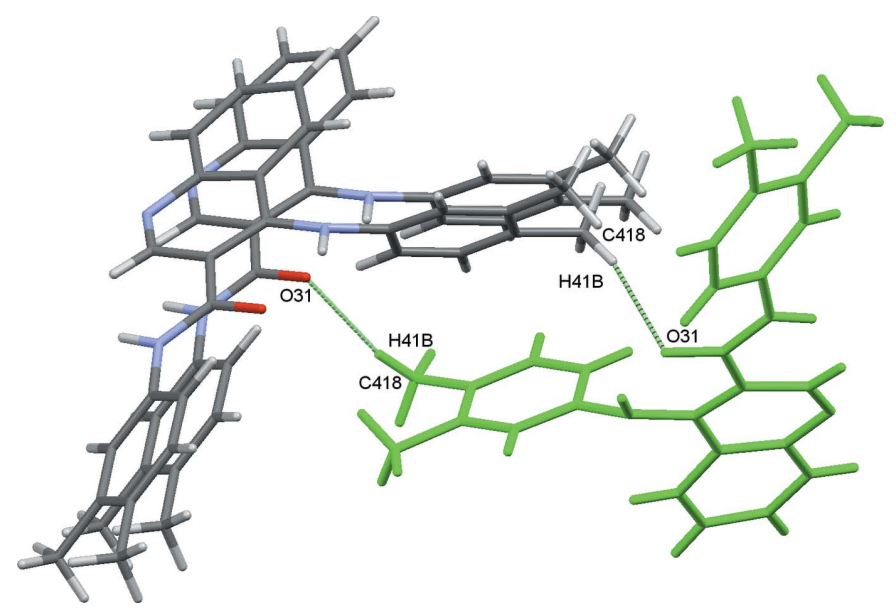

Figure 5

Molecule pairs IIIa/IIIb: $\left(x+\frac{1}{2},-y+\frac{1}{2}, z+1\right.$ (top) and $x-\frac{1}{2},-y+\frac{1}{2}, z+1$ (bottom). Values of energies by pair: $E_{\mathrm{tot}}=-30.0 \mathrm{~kJ} \mathrm{~mol}^{-1}, E_{\text {coul }}=$ $-11.3 \mathrm{~kJ} \mathrm{~mol}^{-1}, E_{\mathrm{pol}}=-4.5 \mathrm{~kJ} \mathrm{~mol}^{-1}, E_{\mathrm{disp}}=-36.0 \mathrm{~kJ} \mathrm{~mol}^{-1}, E_{\mathrm{rep}}=$ $21.8 \mathrm{~kJ} \mathrm{~mol}^{-1}$. Interaction energies were calculated using PIXEL3.1 (Gavezzotti, 2003, 2008) based on densities computed with G09 using the $\mathrm{mp} 2 / 6-31 * *$ level of theory.

above. The analyses were generated using Crystal Explorer 3.1 (Wolff et al., 2012). The lattice energies for $\mathbf{1}$ were analysed after performing calculations as implemented in the PIXEL program (Gavezzotti, 2003, 2008). The total stabilization energy of the crystal packing, $E_{\text {tot }}$ is $-207.0 \mathrm{~kJ} \mathrm{~mol}^{-1}$, distributed as Coulombic, $\left(E_{\text {coul }}=-112.9 \mathrm{~kJ} \mathrm{~mol}^{-1}\right)$, polarization $\left(E_{\mathrm{pol}}=-52.8 \mathrm{~kJ} \mathrm{~mol}^{-1}\right)$, dispersion $\left(E_{\mathrm{disp}}=\right.$ $\left.-251.6 \mathrm{~kJ} \mathrm{~mol}^{-1}\right)$ and repulsion $\left(E_{\mathrm{rep}}=210.4 \mathrm{~kJ} \mathrm{~mol}^{-1}\right)$. The dispersive energy contributes the most to the total stabilization energy of the lattice, in addition to the $\mathrm{C}-\mathrm{H} \cdots \mathrm{O}$ hydrogen bonds, and to the $\mathrm{C}-\mathrm{H} \cdots \pi$ interaction. The stabilization energy comes from six sub-structural motifs made by the molecule pairs $\mathbf{I}$ to VI that are shown in Figs. 3 to 8, together with the symmetry codes as well as the respective energies. They contribute a total energy of $-369.4 \mathrm{~kJ} \mathrm{~mol}^{-1}$ for the lattice, half of it, $-184.7 \mathrm{~kJ} \mathrm{~mol}^{-1}$ attributed to the $(x$, $y, z)$ molecule. That energy corresponds approximately to $88 \%$ of the total stabilization energy of the network.

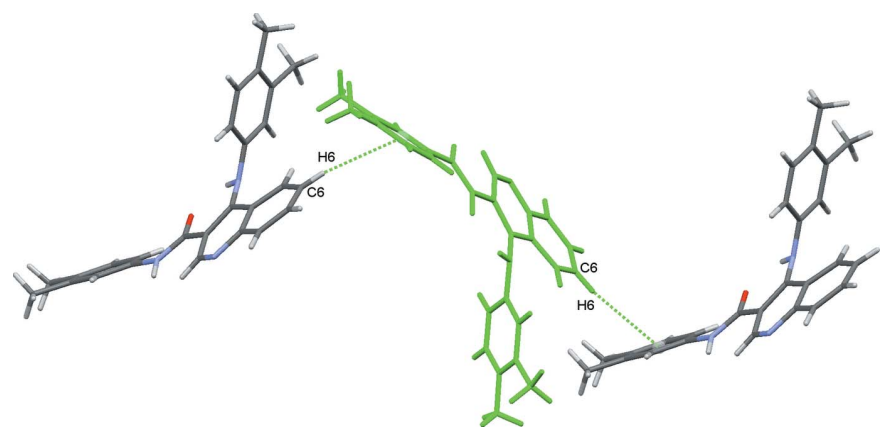

Figure 6

Molecule pairs IVa/IVb: $-x+\frac{1}{2},-y+1, z+\frac{1}{2}$ (left) and $-x+\frac{1}{2},-y+1, z-\frac{1}{2}$ (right). Values of energies by pair: $E_{\text {tot }}=-20.7 \mathrm{~kJ} \mathrm{~mol}^{-1}, E_{\text {coul }}=$ $-7.4 \mathrm{~kJ} \mathrm{~mol}^{-1}, E_{\mathrm{pol}}=-4.4 \mathrm{~kJ} \mathrm{~mol}^{-1}, E_{\text {disp }}=-31.3 \mathrm{~kJ} \mathrm{~mol}^{-1}, E_{\mathrm{rep}}=$ $22.5 \mathrm{~kJ} \mathrm{~mol}^{-1}$. Interaction energies were calculated using PIXEL3.1 (Gavezzotti, 2003, 2008) based on densities computed with G09 using the $\mathrm{mp} 2 / 6-31 * *$ level of theory. 
Table 2

Percentages for atom $\cdots$ atom close contacts.

\begin{tabular}{|c|c|c|c|c|c|c|c|c|}
\hline Compound & $\mathrm{H} \cdots \mathrm{H}$ & $\mathrm{H} \cdots \mathrm{O} / \mathrm{O} \cdots \mathrm{H}$ & $\mathrm{H} \cdots \mathrm{C} / \mathrm{C} \cdots \mathrm{H}$ & $\mathrm{C} \cdots \mathrm{C}$ & $\mathrm{O} \cdots \mathrm{C} / \mathrm{C} \cdots \mathrm{O}$ & $\mathrm{N} \cdots \mathrm{N}$ & $\mathrm{H} \cdots \mathrm{N} / \mathrm{N} \cdots \mathrm{H}$ & $\mathrm{C} \cdots \mathrm{N} / \mathrm{N} \cdots \mathrm{C}$ \\
\hline 1 & 58.4 & 4.3 & 27.0 & 2.5 & 0.6 & 0.2 & 6.5 & 0.5 \\
\hline
\end{tabular}

The percentages of atom - atom close contacts taken from the FP plot (McKinnon et al., 2004) for 1 shows that, apart from the $\mathrm{H} \cdots \mathrm{H}$ contacts $(58.4 \%)$, there are high percentages of $\mathrm{C} \cdots \mathrm{H} / \mathrm{H} \cdots \mathrm{C}$ close contacts $(27.0 \%)$ and of $\mathrm{N} \cdots \mathrm{H} / \mathrm{H} \cdots \mathrm{N}$ close contacts $(6.5 \%)$, see Table 2 .

Apart from the intramolecular hydrogen bond with N41, the carboxyl oxygen atom $\mathrm{O} 31$ involves its lone pairs in another two intermolecular $\mathrm{C}-\mathrm{H} \cdots \mathrm{O}$ interactions, $\mathrm{O} 31 \cdots \mathrm{H} 416-\mathrm{C} 416$ and $\mathrm{O} 31 \cdots \mathrm{H} 41 B-\mathrm{C} 418$. The first inter-

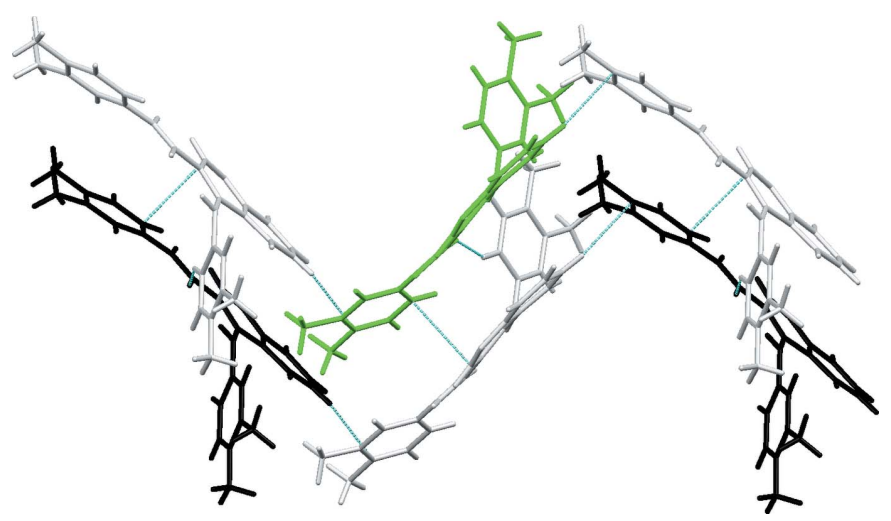

Figure 7

Molecule pairs Va/Vb: $-x+\frac{3}{2}, y+1, z-\frac{1}{2}$ (left) and $-x+\frac{3}{2}, y+1, z+\frac{1}{2}$ (right). Values of energies by pair: $E_{\text {tot }}=-14.5 \mathrm{~kJ} \mathrm{~mol}^{-1}, E_{\text {coul }}=$ $-5.0 \mathrm{~kJ} \mathrm{~mol}^{-1}, E_{\mathrm{pol}}=-2.5 \mathrm{~kJ} \mathrm{~mol}^{-1}, E_{\mathrm{disp}}=-23.4 \mathrm{~kJ} \mathrm{~mol}^{-1}, E_{\mathrm{rep}}=$ $16.4 \mathrm{~kJ} \mathrm{~mol}^{-1}$. Interaction energies were calculated using PIXEL3.1 (Gavezzotti, 2003, 2008) based on densities computed with G09 using the $\mathrm{mp} 2 / 6-31 * *$ level of theory.

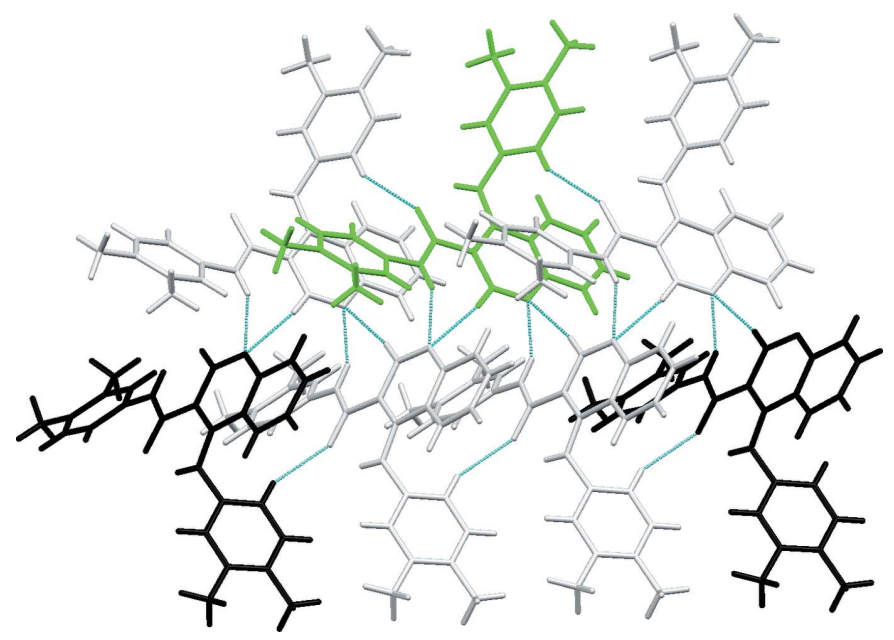

Figure 8

Molecule pairs VIa/VIb, $\left(x-\frac{3}{2},-y+\frac{3}{2},-z+1\right.$ (left) and $x-\frac{3}{2},-y+\frac{3}{2}$, $-z+1$ (right). Values of energies by pair: $E_{\mathrm{tot}}=-11.3 \mathrm{~kJ} \mathrm{~mol}^{-1}, E_{\mathrm{coul}}=$ $-3.3 \mathrm{~kJ} \mathrm{~mol}^{-1}, E_{\mathrm{pol}}=-2.2 \mathrm{~kJ} \mathrm{~mol}^{-1}, E_{\mathrm{disp}}=-15.5 \mathrm{~kJ} \mathrm{~mol}^{-1}, E_{\mathrm{rep}}=$ $9.6 \mathrm{~kJ} \mathrm{~mol}^{-1}$. Interaction energies were calculated using PIXEL3.1 (Gavezzotti, 2003, 2008) based on densities computed with G09 using the mp2/6-31** level of theory. action creates chains running along the $a$-axis direction that are further stabilized by $\mathrm{C}-\mathrm{H} \cdots \pi$ interactions (C326$\left.\mathrm{H} 326 \cdots C g_{\text {pyridine }}\right)$, as can be identified by the red spots in the Hirshfeld Surface (McKinnon et al., 2004) for the molecule, Fig. 9, and they form two molecule pairs, identified as substructures Ia/Ib in Fig. 3. Each of those pairs contribute $-55.9 \mathrm{~kJ} \mathrm{~mol}^{-1}$ to the stabilization of the lattice, mainly dispersion energy. The second interaction, O31 $\cdots \mathrm{H} 41 B-$ C418, makes another two molecule pairs, IIIa/IIIb, Fig. 5. In this substructure the Coulombic energy is higher than the dispersive energy, which is indicative of the minor importance of the interactions involving the aromatic rings. These hydrogen bonds can also be identified as red spots in the HS, Fig. 9.

The nitrogen atom $\mathrm{N} 32$ acts as a donor for $\mathrm{N} 1$ (N32$\mathrm{H} 32 \cdots \mathrm{N} 1)$. N1 also acts as an acceptor for C6, making a C6H6 . N1 hydrogen bond, seen as a red spot in Fig. 9. Those interactions give sub structural motifs IIa/IIb, Fig. 4. The molecules are linked by $\mathrm{N} 32-\mathrm{H} 32 \cdots \mathrm{N} 1\left(x+\frac{1}{2},-y+\frac{3}{2},-z+1\right)$ hydrogen bonds, forming $C 6$ chains which run parallel to the $a$-axis direction, formed by the action of the $2_{1}$ screw axis at $\left(\frac{1}{2}\right.$, $\left.0, \frac{3}{4}\right)$. This is supplemented by the weak $\mathrm{C} 2-\mathrm{H} 2 \cdots \mathrm{N} 1\left(x+\frac{1}{2}\right.$, $\left.-y+\frac{3}{2},-z+1\right)$ hydrogen bond, Figs. 3 and 4 .

In addition, the $\mathrm{C}-\mathrm{H} \cdots \pi$ interaction can also be identified in the HS of the molecule, Fig. 9. The interaction connects the molecules in zigzag chains running along the $c$-axis direction, as a result of the propagation of the molecule pairs $\mathbf{I V a} / \mathbf{I V b}$ depicted in Fig. 6.
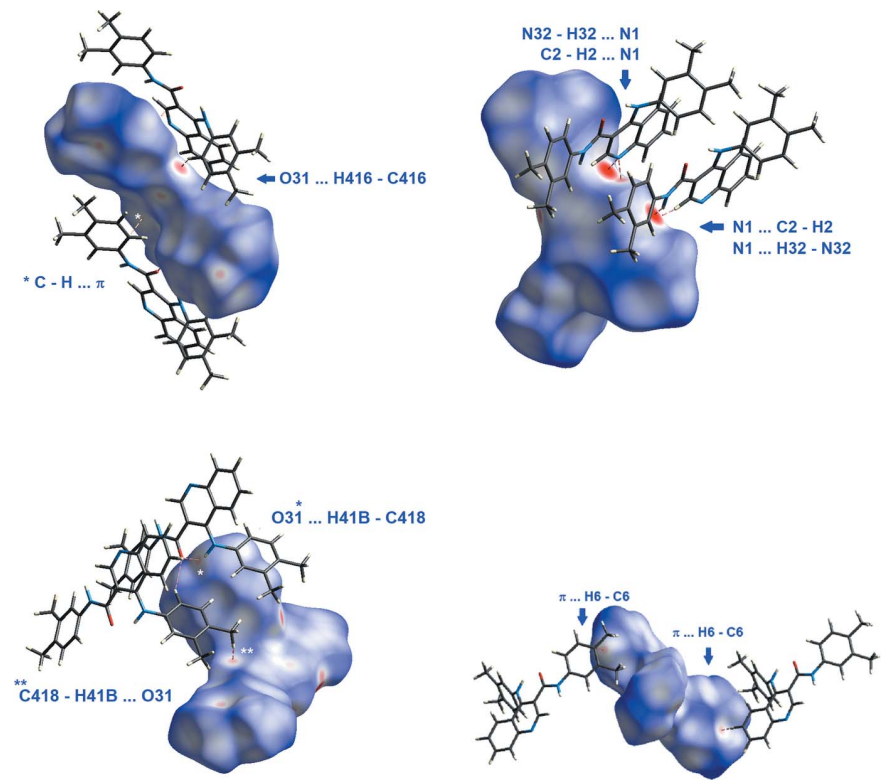

Figure 9

Several faces of the HS plotted over $d_{\text {norm }}$ for $\mathbf{1}$ showing the red spots that indicate close contacts between atoms, which are identified in the figures. 
Apart from the sub-structural motifs described, there are two extra molecule pairs, identified as $\mathbf{V a} / \mathbf{V b}$ and $\mathbf{V I a} / \mathbf{V I b}$, which are also illustrated in Figs. 7 and 8: the two molecules involved are at $x, y, z$ (green-coloured molecule) and $-x+\frac{3}{2}$, $-y+1, z-\frac{1}{2} /-x+\frac{3}{2},-y+1, z+\frac{1}{2}$ (black-coloured molecule) for $\mathbf{V a} / \mathbf{V b}$ and $x-\frac{3}{2},-y+\frac{3}{2},-z+1 / x-\frac{3}{2},-y+\frac{3}{2},-z+1$ for VIa/VIb. Although these molecules do not exhibit atom $\cdots$ atom close contacts, each pair provides a significant contribution to the overall lattice stabilization energy of -14.5 and $-11.3 \mathrm{~kJ} \mathrm{~mol}^{-1}$, respectively for $\mathbf{V}$ and VI. The grey molecules drawn in this figure indicate a possible pathway for electronic delocalization within the network of molecules.

\section{Database survey}

A search of the Cambridge Structural Database (CSD, Version 5.40, November 2019 update; Groom et al., 2016) for 3,4-disubstituted quinoline with an $\mathrm{N}-\mathrm{H}$ unit attached to $\mathrm{C} 4$ revealed two compounds: SEZJIR (3-acetyl-4-aminoquinoline; Lokaj et al., 2007) with a carbonyl group attached to $\mathrm{C} 3$ and an amino group attached to C4 and PABPUD [4-[3( $N, N$-dimethylamino)propylamino]-3-nitroquinoline; Boyd et al., 1992\} with an amino group attached to $\mathrm{C} 4$ and a nitro group attached to $\mathrm{C} 3$. In both of these compounds, there is no puckering of the pyridine ring and the quinoline ring system is essentially planar. In both cases, a hydrogen atom forms an intramolecular hydrogen bond between an amino hydrogen and the carbonyl oxygen in both independent molecules of the asymmetric unit (SEZJIR) or between the amino hydrogen and a nitro group oxygen atom (PABPUD). In both structures, the $\mathrm{C}$ (pyridine) $\cdots \mathrm{N}$ (amino) distances are significantly shorter than those in $\mathbf{1}, v i z .1 .325$ and $1.335 \AA$ for the two molecules in the asymmetric unit of SEZJIR and $1.320 \AA$ in PABPUD. The corresponding value in $\mathbf{1}$ is 1.364 (3) $\AA$.

A survey of quinoline compounds, with an $R$ factor of $10 \%$ or less with a $\mathrm{C}_{\text {quinoline }}-\mathrm{NH}-\mathrm{C}_{\text {aryl } / s p^{3}}$ unit attached to $\mathrm{C} 4$ of the quinoline moiety gave 56 hits for 63 individual molecules, including 1 . The $\mathrm{C}_{\text {quinoline }}-\mathrm{N}$ distances lie in the range 1.319 to $1.438 \AA$ with an average value of $1.360 \AA$.

The situation is more complex for the $\mathrm{N}-\mathrm{C}_{\mathrm{ary} 1 / s p^{3}}$ bond and for the $\mathrm{C}_{\text {quinoline }}-\mathrm{N}-\mathrm{C}_{\mathrm{aryl} / s p^{3}}$ angle. A scatterplot of these revealed two populations, one in which the $\mathrm{N}$ atom is attached to a benzene ring and the other in which the connection is to an $s p^{3}$ carbon. UNIKUZ [6-( $t$-butylsulfonyl)- $\mathrm{N}$-(5-fluoro- $1 \mathrm{H}$ indazol-3-yl)quinolin-4-amine methanol solvate; Haile et al., 2016 ) is included in the first group. The $\mathrm{C}_{\text {aryl }}-\mathrm{N}$ distances lie in the range 1.396 to $1.438 \AA$ with an average value of $1.418 \AA$ and an average $\mathrm{C}_{\text {quinoline }}-\mathrm{N}-\mathrm{C}_{\mathrm{aryl} / s p^{3}}$ angle of $126.105^{\circ}$. In the second case, the $\mathrm{C}_{\text {aryl } / s p^{3}}-\mathrm{N}$ distances lie in the range 1.439 to $1.478 \AA$ with an average value of $1.458 \AA$, with an average $\mathrm{C}_{\text {quinoline }}-\mathrm{N}-\mathrm{C}_{\text {aryl } / s p^{3}}$ angle of $123.98^{\circ}$.

As noted above, the conformation around the amino $\mathrm{N}$ atom is slightly pyramidal. In their paper on bond lengths in organic compounds, Allen et al. (2006) discuss the planarity and pyramidality of amino compounds. They state that for planar $\mathrm{N}$ atoms, the mean valence angle is greater than $117.6^{\circ}$ while for pyramidal $\mathrm{N}$ atoms the mean valence angle lies in the range 108 to $114^{\circ}$. The value for $\mathbf{1}$ is $117.56^{\circ}$. There are three other structures in this survey which have average valence angles close to but less than $117^{\circ}$. The valence angles are $116.57^{\circ}$ in DAMIOT $\{2,3$-bis[(2,6-dimethylphenyl)sulfanyl]- $N$ phenylquinolin-4-amine; Florke \& Egold, 2016\}, $117.41^{\circ}$ in MEQKEY (2,4-dianilino-3-ethylquinoline; Katritzky et al., $2000)$ and $117.04^{\circ}$ in OTAMOM (2-(4-methoxyphenyl)- $N$-[2(2-phenylvinyl)phenyl]quinolin-4-amine; Mphahlele \& Mphahlele, 2011\}. These four compounds are thus neither strictly planar nor pyramidal.

There are two compounds in the database which have an amide group attached to C3, GICGIL [2-chloro- $N$-(4-fluorophenyl)-6-methylquinoline-3-carboxamide; Govender et al., 2018] and SUZHEB ( $N$-isopropyl-6-methyl-2-phenylquinoline-3-carboxamide; Benzerka et al., 2010). In both these compounds, the amide group is inclined to the quinoline moiety, unlike in molecule $\mathbf{1}$.

\section{Synthesis and crystallization}

The title quinolone derivative $\mathbf{1}$ was synthesized by a one-pot reaction between 4-oxo-1,4-dihydroquinoline-3-carboxylic acid and 3,4-dimethylaniline in the presence of $\mathrm{POCl}_{3}$ following a procedure described previously (Cagide et al., 2015). The title compound was obtained in $70 \%$ yield and characterized by NMR. It was re-crystallized from dichloromethane to yield crystals suitable for X-ray diffraction, m.p. 489-493 K.

NMR data were acquired on a Bruker AMX 400 spectrometer, recorded at room temperature in $5 \mathrm{~mm}$ outer-diameter tubes. The samples were prepared in deuterated dimethylsulfoxide (DMSO) with tetramethylsilane (TMS) as internal reference. Chemical shifts are expressed as $\delta(\mathrm{ppm})$ values relative to TMS; coupling constants $(J)$ are given in Hz. Atoms are labelled with their numerical designation as per Fig. 1. See Supporting Information for spectra.

4-(3,4-Dimethylanilino)- $\mathbf{N}$-(3,4-dimethylphenyl)quinoline3-carboxamide

${ }^{1} \mathrm{H}$ NMR (400 MHz, DMSO): $10.16(1 \mathrm{H}, s, \mathrm{CONH}), 9.43$ $(1 \mathrm{H}, s, \mathrm{NH}), 8.82(1 \mathrm{H}, s, \mathrm{H}-2), 8.14(1 \mathrm{H}, d d, J=1.0,8.5 \mathrm{~Hz}, \mathrm{H}-$ 8), $7.95(1 \mathrm{H}, d d, J=0.84,8.4 \mathrm{~Hz}, \mathrm{H}-5), 7.73(1 \mathrm{H}, d d d, J=1.0$, $6.9,8.4 \mathrm{~Hz}, \mathrm{H}-6), 7.46(1 \mathrm{H}, d d d, J=1.0,6.9,8.5 \mathrm{~Hz}, \mathrm{H}-7), 7.18$ $(1 \mathrm{H}, d, J=2.0 \mathrm{~Hz}, \mathrm{H}-412), 7.12(1 \mathrm{H}, d d, J=2.1,8.0 \mathrm{~Hz} \mathrm{H}-326)$, $7.00(1 \mathrm{H}, d, J=8.0 \mathrm{~Hz}, \mathrm{H}-325), 6.93(1 \mathrm{H}, d, J=8.0 \mathrm{~Hz}, \mathrm{H}-415)$, $6.84(1 \mathrm{H}, d, J=2.1 \mathrm{~Hz}, \mathrm{H}-322), 6.72(1 \mathrm{H}, d d, J=2.0,8.0 \mathrm{~Hz}, \mathrm{H}-$ 416), $2.01\left(3 \mathrm{H}, s, \mathrm{CH}_{3}\right), 2.07\left(3 \mathrm{H}, s, \mathrm{CH}_{3}\right), 2.16(6 \mathrm{H}, s, 2 \times$ $\mathrm{CH}_{3}$ ).

${ }^{13} \mathrm{C}$ NMR (100 MHz, DMSO): 165.4 (CONH), 149.9 (C-2), 149.1 (C-8A), 146.6 (C-4), 140.3 (C-411), 136.5 (C-414), 136.3 (C-321), 135.6 (C-324), 131.2 (C-413), 130.5 (C-323), 130.2 (C6), 129.6 (C-415), 129.2 (C-5), 129.0 (C-325), 125.0 (C-7), 124.2 (C-8), 121.6 (C-412), 121.5 (C-322), 120.8 (C-4A), 117.8 (C325), 117.7 (C-416), 114.4 (C-3), $19.5\left(\mathrm{CH}_{3}\right), 19.3\left(\mathrm{CH}_{3}\right), 18.7$ $\left(\mathrm{CH}_{3}\right), 18.5\left(\mathrm{CH}_{3}\right)$. 


\section{Refinement}

Crystal data, data collection and structure refinement details are summarized in Table 3. The $\mathrm{H}$ atoms were included in idealized positions and treated as riding atoms: $\mathrm{C}-\mathrm{H}=0.95-$ $0.98 \AA$ with $U_{\text {iso }}(\mathrm{H})=1.2 U_{\text {eq }}(\mathrm{C})$ or $1.5 U_{\text {eq }}(\mathrm{C})$ for methyl $\mathrm{H}$ atoms. Those attached to $\mathrm{N}$ and $\mathrm{C} 2[\mathrm{C}-\mathrm{H}=0.96$ (3) $\AA$ ] were refined. The latter was refined since it is involved in a short contact with $\mathrm{H} 32$, which is attached to N32. Although in the riding model for $\mathrm{H} 2$ the $\mathrm{H}$-atom position is within the highest contour on the difference map, it is not at the centre. In the refined model it is. The $\mathrm{H} \cdots \mathrm{H}$ distances are 1.87 and $1.93 \AA$ for the riding and refined models, respectively. The angles around $\mathrm{C} 2$ are $\mathrm{N} 1-\mathrm{C} 2-\mathrm{C} 3=125.9(3)$ and $125.9^{\circ}(3) ; \mathrm{N}-$ $\mathrm{C} 2-\mathrm{H} 2=117$ and $111.9(17)^{\circ}$ and $\mathrm{C} 3-\mathrm{C} 2-\mathrm{H} 2=117$ and $122.2(17)^{\circ}$ for riding and refined $\mathrm{H}$ atoms, respectively. In the case of $\mathrm{H} 32$, the $\mathrm{N} 32-\mathrm{H} 32$ distance changes from 0.89 (3) to 0.90 (4) $\AA$ and the angle $\mathrm{C} 31-\mathrm{N} 32-\mathrm{H} 32$ changes from 120 (2) to $119(2)^{\circ}$ for riding to refined, respectively, which are really insignificant shifts. Hence, in this case the short contact does induce a shift in the angular position of $\mathrm{H} 2$ from its calculated position.

\section{Acknowledgements}

The authors thank the staff at the National Crystallographic Service, University of Southampton, for the data collection, help and advice (Coles \& Gale, 2012).

\section{Funding information}

This work was funded by FEDER funds through the Operational Programme Competitiveness Factors - COMPETE and national funds by the FCT - Foundation for Science and Technology -under research grants UID/QUI/00081 and PTDC/ASP-PES/28397/2017.

\section{References}

Allen, F. R., Watson, D. G., Brammer, L., Orpen, A. G. \& Taylor, R. (2006). International Tables for Crystallography, Vol. C, ch. 9.5, pp. 790-811. Chester: IUCr

Antony, H. A. \& Parija, S. C. (2016). Trop. Parasitol. 6, 30-41.

Benzerka, S., Bouraiou, A., Bouacida, S., Roisnel, T. \& Belfaitah, A. (2010). Acta Cryst. E66, o2304-o2305.

Boyd, M., Boyd, P. D. W., Atwell, G. J., Wilson, W. R. \& Denny, W. A. (1992). J. Chem. Soc. Perkin Trans. 2, pp. 579-585.

Cagide, F., Silva, T., Reis, J., Gaspar, A., Borges, F., Gomes, L. R. \& Low, J. N. (2015). Chem. Commun. 51, 2832-2835.

Coles, S. J. \& Gale, P. A. (2012). Chem. Sci. 3, 683-689.

Florke, U. \& Egold, H. (2016). Private Communication (refcode DAMIOT). CCDC, Cambridge, England.

Gavezzotti, A. (2003). J. Phys. Chem. B, 107, 2344-2353.

Gavezzotti, A. (2008). Mol. Phys. 106, 1473-1485.

Gomes, L. R., Low, J. N., Cagide, F., Chavarria, D. \& Borges, F. (2015a). Acta Cryst. E71, 547-554.

Gomes, L. R., Low, J. N., Cagide, F., Gaspar, A. \& Borges, F. (2015b). Acta Cryst. E71, 1270-1277.

Gomes, L. R., Low, J. N., Fonseca, A., Matos, M. J. \& Borges, F. (2016). Acta Cryst. E72, 926-932.

Govender, H., Mocktar, C. \& Koorbanally, N. A. (2018). J. Heterocycl. Chem. 55, 1002-1009.
Table 3

Experimental details.

\begin{tabular}{ll}
\hline Crystal data & \\
Chemical formula & $\mathrm{C}_{26} \mathrm{H}_{25} \mathrm{~N}_{3} \mathrm{O}$ \\
$M_{\mathrm{r}}$ & 395.49 \\
Crystal system, space group & Orthorhombic, $P 2_{1} 2_{1} 2_{1}$ \\
Temperature $(\mathrm{K})$ & 100 \\
$a, b, c(\AA)$ & $6.2502(3), 15.7915(6), 20.7395(9)$ \\
$V\left(\AA^{3}\right)$ & $2046.99(15)$ \\
$Z$ & 4 \\
Radiation type & $\mathrm{Mo} \mathrm{K \alpha}$ \\
$\mu\left(\mathrm{mm}^{-1}\right)$ & 0.08 \\
Crystal size $(\mathrm{mm})$ & $0.30 \times 0.05 \times 0.01$
\end{tabular}

Data collection

Diffractometer

Absorption correction

$T_{\min }, T_{\max }$

No. of measured, independent and observed $[I>2 \sigma(I)]$ reflections

$R_{\text {int }}$
$(\sin \theta / \lambda)_{\max }\left(\AA^{-1}\right)$

Refinement

$R\left[F^{2}>2 \sigma\left(F^{2}\right)\right], w R\left(F^{2}\right), S$

No. of reflections

No. of parameters

$\mathrm{H}$-atom treatment

$\Delta \rho_{\max }, \Delta \rho_{\min }\left(\mathrm{e} \AA^{-3}\right)$

Absolute structure

Absolute structure parameter

Rigaku FRE+ equipped with VHF
Varimax confocal mirrors and an
AFC12 goniometer and HyPix
6000 detector
Multi-scan (CrysAlis PRO; Rigaku
OD, 2018)
$0.487,1.000$
$28997,3754,3390$
0.089
0.602

$0.044,0.094,1.08$
3754
287
H atoms treated by a mixture of
independent and constrained
refinement
$0.22,-0.20$
Flack $x$ determined using 1238
quotients $\left[\left(I^{+}\right)-\left(I^{-}\right)\right] /\left[\left(I^{+}\right)+\left(I^{-}\right)\right]$
(Parsons et al., 2013$)$
$0.2(10)$

Computer programs: CrysAlis PRO (Rigaku OD, 2018), SHELXT (Sheldrick, 2015a), ShelXle (Hübschle et al., 2011), SHELXL2014/7 (Sheldrick, 2015b), OSCAIL (McArdle et al., 2004), Mercury (Macrae et al., 2006) and PLATON (Spek, 2020).

Groom, C. R., Bruno, I. J., Lightfoot, M. P. \& Ward, S. C. (2016). Acta Cryst. B72, 171-179.

Haile, P. A., Votta, B. J., Marquis, R. W., Bury, M. J., Mehlmann, J. F., Singhaus, R. Jr, Charnley, A. K., Lakdawala, A. S., Convery, M. A., Lipshutz, D. B., Desai, B. M., Swift, B., Capriotti, C. A., Berger, S. B., Majahan, M. K., Reilly, M. A., Rivera, E. J., Sun, H. H., Nagilla, R., Beal, A. M., Finger, J. N., Cook, M. N., King, B. W., Ouellette, M. T., Totoritis, R. D., Pierdomenico, M., Negroni, A., Stronati, L., Cucchiara, S., Ziolkowski, B., Vossenkamper, A., MacDonald, T. T., Gough, P. J., Bertin, J. \& Casillas, L. N. (2016). J. Med. Chem. 59, 4876-4880.

Hübschle, C. B., Sheldrick, G. M. \& Dittrich, B. (2011). J. Appl. Cryst. 44, 1281-1284.

Katritzky, A. R., Huang, T.-B., Voronkov, M. V. \& Steel, P. J. (2000). J. Org. Chem. 65, 8069-8073.

Lokaj, J., Kettmann, V., Černuchová, P., Milata, V. \& Fronc, M. (2007). Acta Cryst. E63, o1164-o1166.

Macrae, C. F., Edgington, P. R., McCabe, P., Pidcock, E., Shields, G. P., Taylor, R., Towler, M. \& van de Streek, J. (2006). J. Appl. Cryst. 39, 453-457.

McArdle, P., Gilligan, K., Cunningham, D., Dark, R. \& Mahon, M. (2004). CrystEngComm, 6, 303-309.

McKinnon, J. J., Spackman, M. A. \& Mitchell, A. S. (2004). Acta Cryst. B60, 627-668.

Mphahlele, M. J. \& Mphahlele, M. M. (2011). Tetrahedron, 67, 46894695. 
Mugnaini, C., Pasquini, S. \& Corelli, F. (2009). Curr. Med. Chem. 16, 1746-1767.

Musiol, R. (2017). Exp. Opin. Drug. Discov. 12, 583-597.

Nainwal, L. M., Tasneem, S., Akhtar, W., Verma, G., Khan, M. F., Parvez, S., Shaquiquzzaman, M., Akhter, M. \& Alam, M. M. (2019). Eur. J. Med. Chem. 164, 121-170.

Parsons, S., Flack, H. D. \& Wagner, T. (2013). Acta Cryst. B69, 249259.
Rigaku OD (2018). CrysAlis PRO. Rigaku Corporation, Tokyo, Japan.

Sheldrick, G. M. (2015a). Acta Cryst. A71, 3-8.

Sheldrick, G. M. (2015b). Acta Cryst. C71, 3-8.

Spek, A. L. (2020). Acta Cryst. E76, 1-11.

Wolff, S. K., Grimwood, D. I., McKinnon, J. J., Turner, M. J., Jayatilaka, D. \& Spackman, M. A. (2012). Crystal Explorer. The University of Western Australia. 


\section{supporting information}

Acta Cryst. (2020). E76, 201-207 [https://doi.org/10.1107/S2056989020000298]

\section{The synthesis, crystal structure and Hirshfeld analysis of 4-(3,4-dimethyl- anilino)-N-(3,4-dimethylphenyl)quinoline-3-carboxamide}

\section{Ligia R. Gomes, John Nicolson Low, Fernanda Borges, Alexandra Gaspar and Francesco Mesiti}

Computing details

Data collection: CrysAlis PRO (Rigaku OD, 2018); cell refinement: CrysAlis PRO (Rigaku OD, 2018); data reduction: CrysAlis PRO (Rigaku OD, 2018); program(s) used to solve structure: OSCAIL (McArdle et al., 2004) and SHELXT (Sheldrick, 2015a); program(s) used to refine structure: OSCAIL (McArdle et al., 2004), ShelXle (Hübschle et al., 2011) and SHELXL2014/7 (Sheldrick, 2015b); molecular graphics: Mercury (Macrae et al., 2006); software used to prepare material for publication: OSCAIL (McArdle et al., 2004), SHELXL2014 (Sheldrick, 2015b) and PLATON (Spek, 2020).

4-(3,4-Dimethylanilino)-N-(3,4-dimethylphenyl)quinoline-3-carboxamide

Crystal data

$\mathrm{C}_{26} \mathrm{H}_{25} \mathrm{~N}_{3} \mathrm{O}$

$M_{r}=395.49$

Orthorhombic, $P 22_{1} 2_{1} 2_{1}$

$a=6.2502(3) \AA$

$b=15.7915(6) \AA$

$c=20.7395(9) \AA$

$V=2046.99(15) \AA^{3}$

$Z=4$

$F(000)=840$

\section{Data collection}

Rigaku FRE+ equipped with VHF Varimax confocal mirrors and an AFC12 goniometer and HyPix 6000 detector diffractometer

Radiation source: Rotating Anode, Rigaku FRE+

Confocal mirrors, VHF Varimax monochromator

Detector resolution: 10 pixels $\mathrm{mm}^{-1}$

profile data from $\omega$-scans

Refinement

Refinement on $F^{2}$

Least-squares matrix: full

$R\left[F^{2}>2 \sigma\left(F^{2}\right)\right]=0.044$

$w R\left(F^{2}\right)=0.094$

$S=1.08$

3754 reflections
$D_{\mathrm{x}}=1.283 \mathrm{Mg} \mathrm{m}^{-3}$

Mo $K \alpha$ radiation, $\lambda=0.71075 \AA$

Cell parameters from 5133 reflections

$\theta=1.6-27.0^{\circ}$

$\mu=0.08 \mathrm{~mm}^{-1}$

$T=100 \mathrm{~K}$

Needle, yellow

$0.30 \times 0.05 \times 0.01 \mathrm{~mm}$

Absorption correction: multi-scan

(CrysAlis PRO; Rigaku OD, 2018)

$T_{\min }=0.487, T_{\max }=1.000$

28997 measured reflections

3754 independent reflections

3390 reflections with $I>2 \sigma(I)$

$R_{\text {int }}=0.089$

$\theta_{\text {max }}=25.4^{\circ}, \theta_{\text {min }}=1.6^{\circ}$

$h=-7 \rightarrow 7$

$k=-19 \rightarrow 19$

$l=-24 \rightarrow 24$

287 parameters

0 restraints

Primary atom site location: structure-invariant direct methods

Secondary atom site location: structureinvariant direct methods 
Hydrogen site location: mixed

$\mathrm{H}$ atoms treated by a mixture of independent and constrained refinement

$w=1 /\left[\sigma^{2}\left(F_{\mathrm{o}}^{2}\right)+(0.0402 P)^{2}+0.5091 P\right]$

where $P=\left(F_{\mathrm{o}}^{2}+2 F_{\mathrm{c}}^{2}\right) / 3$

$(\Delta / \sigma)_{\max }<0.001$
$\Delta \rho_{\max }=0.22$ e $\AA^{-3}$

$\Delta \rho_{\min }=-0.20$ e $\AA^{-3}$

Absolute structure: Flack $x$ determined using

1238 quotients $\left[\left(I^{+}\right)-\left(I^{-}\right)\right] /\left[\left(I^{+}\right)+\left(I^{-}\right)\right]$(Parsons et al., 2013)

Absolute structure parameter: 0.2 (10)

\section{Special details}

Geometry. All esds (except the esd in the dihedral angle between two 1.s. planes) are estimated using the full covariance matrix. The cell esds are taken into account individually in the estimation of esds in distances, angles and torsion angles; correlations between esds in cell parameters are only used when they are defined by crystal symmetry. An approximate (isotropic) treatment of cell esds is used for estimating esds involving 1.s. planes.

Fractional atomic coordinates and isotropic or equivalent isotropic displacement parameters $\left(\AA^{2}\right)$

\begin{tabular}{|c|c|c|c|c|}
\hline & $x$ & $y$ & $z$ & $U_{\text {iso }} * / U_{\text {eq }}$ \\
\hline $\mathrm{O} 31$ & $0.5597(3)$ & $0.49964(12)$ & $0.49759(10)$ & $0.0221(5)$ \\
\hline N1 & $-0.0092(4)$ & $0.69133(14)$ & $0.44267(11)$ & $0.0174(5)$ \\
\hline N32 & $0.5344(4)$ & $0.62696(15)$ & $0.54659(11)$ & $0.0162(5)$ \\
\hline H32 & $0.470(5)$ & $0.678(2)$ & $0.5477(15)$ & $0.028(9)^{*}$ \\
\hline N41 & $0.2497(4)$ & $0.44714(15)$ & $0.42129(13)$ & $0.0195(5)$ \\
\hline H41 & $0.368(6)$ & $0.441(2)$ & $0.4400(16)$ & $0.026(9)^{*}$ \\
\hline $\mathrm{C} 2$ & $0.1722(5)$ & $0.66921(17)$ & 0.47005 (13) & $0.0161(6)$ \\
\hline $\mathrm{H} 2$ & $0.233(5)$ & 0.7147 (17) & $0.4948(14)$ & $0.014(7)^{*}$ \\
\hline $\mathrm{C} 3$ & $0.2727(4)$ & $0.58912(17)$ & $0.46478(13)$ & $0.0154(6)$ \\
\hline $\mathrm{C} 4$ & $0.1727(5)$ & $0.52774(16)$ & $0.42608(13)$ & $0.0158(6)$ \\
\hline $\mathrm{C} 5$ & $-0.1008(5)$ & $0.50493(18)$ & $0.33862(13)$ & $0.0196(6)$ \\
\hline H5 & -0.037379 & 0.452194 & 0.327658 & $0.024 *$ \\
\hline $\mathrm{C} 4 \mathrm{~A}$ & -0.0119 & $0.55400(17)$ & $0.38887(13)$ & $0.0161(6)$ \\
\hline C6 & $-0.2769(5)$ & $0.53228(19)$ & $0.30555(15)$ & $0.0237(7)$ \\
\hline H6 & -0.332691 & 0.499128 & 0.271220 & $0.028 *$ \\
\hline $\mathrm{C} 7$ & $-0.3757(5)$ & 0.60896 (19) & $0.32201(15)$ & $0.0241(7)$ \\
\hline $\mathrm{H} 7$ & -0.504081 & 0.625506 & 0.300995 & $0.029 *$ \\
\hline $\mathrm{C} 8$ & $-0.2880(5)$ & $0.65997(19)$ & $0.36813(14)$ & $0.0209(6)$ \\
\hline H8 & -0.352964 & 0.712802 & 0.377996 & $0.025^{*}$ \\
\hline C8A & $-0.1007(5)$ & $0.63448(17)$ & $0.40134(13)$ & $0.0160(6)$ \\
\hline C31 & 0.4680 & $0.56876(16)$ & $0.50328(13)$ & $0.0158(6)$ \\
\hline C321 & $0.7023(4)$ & $0.61744(16)$ & 0.59179 (13) & $0.0146(6)$ \\
\hline C322 & $0.6840(5)$ & $0.66241(17)$ & $0.64919(14)$ & $0.0173(6)$ \\
\hline H322 & 0.559581 & 0.695626 & 0.656408 & $0.021 *$ \\
\hline C323 & $0.8416(4)$ & $0.66032(18)$ & $0.69622(14)$ & $0.0184(6)$ \\
\hline C324 & $1.0277(5)$ & $0.61192(18)$ & $0.68531(13)$ & $0.0181(6)$ \\
\hline C 325 & $1.0432(5)$ & $0.56727(18)$ & $0.62795(14)$ & $0.0191(6)$ \\
\hline H325 & 1.167921 & 0.534397 & 0.620254 & $0.023^{*}$ \\
\hline C326 & $0.8845(4)$ & $0.56865(17)$ & $0.58145(14)$ & $0.0168(6)$ \\
\hline H326 & 0.899709 & 0.536669 & 0.542929 & $0.020 *$ \\
\hline C327 & $0.8115(5)$ & $0.70814(19)$ & $0.75834(15)$ & $0.0250(7)$ \\
\hline $\mathrm{H} 32 \mathrm{~A}$ & 0.934273 & 0.745612 & 0.765419 & $0.037 *$ \\
\hline H32B & 0.800307 & 0.667948 & 0.794181 & $0.037^{*}$ \\
\hline
\end{tabular}




$\begin{array}{lllll}\text { H32C } & 0.680368 & 0.741992 & 0.755852 & 0.037^{*} \\ \text { C328 } & 1.2038(5) & 0.6077(2) & 0.73465(15) & 0.0254(7) \\ \text { H32D } & 1.253251 & 0.665128 & 0.744633 & 0.038^{*} \\ \text { H32E } & 1.323221 & 0.574413 & 0.717458 & 0.038^{*} \\ \text { H32F } & 1.149786 & 0.580841 & 0.774012 & 0.038^{*} \\ \text { C411 } & 0.1222(5) & 0.37148(17) & 0.41833(14) & 0.0194(6) \\ \text { C412 } & 0.2064(5) & 0.30036(17) & 0.38929(13) & 0.0202(7) \\ \text { H412 } & 0.346385 & 0.302560 & 0.371508 & 0.024^{*} \\ \text { C413 } & 0.0886(5) & 0.22452(18) & 0.38552(13) & 0.0192(6) \\ \text { C414 } & -0.1149(5) & 0.22182(18) & 0.41275(14) & 0.0208(7) \\ \text { C415 } & -0.1955(5) & 0.29255(18) & 0.44308(14) & 0.0228(7) \\ \text { H415 } & -0.333552 & 0.290071 & 0.462158 & 0.027^{*} \\ \text { C416 } & -0.0793(5) & 0.36751(18) & 0.44637(14) & 0.0200(6) \\ \text { H416 } & -0.137324 & 0.415606 & 0.467629 & 0.024^{*} \\ \text { C417 } & 0.1826(5) & 0.14893(18) & 0.35187(16) & 0.0275(7) \\ \text { H41D } & 0.090414 & 0.132683 & 0.315709 & 0.041^{*} \\ \text { H41E } & 0.193326 & 0.101625 & 0.382290 & 0.041^{*} \\ \text { H41F } & 0.325447 & 0.163163 & 0.335672 & 0.041^{*} \\ \text { C418 } & -0.2461(5) & 0.14148(19) & 0.40803(16) & 0.0281(7) \\ \text { H41A } & -0.384750 & 0.150125 & 0.429087 & 0.042^{*} \\ \text { H41B } & -0.169739 & 0.095098 & 0.429390 & 0.042^{*} \\ \text { H41C } & -0.268722 & 0.127195 & 0.362554 & 0.042^{*}\end{array}$

Atomic displacement parameters $\left(\AA^{2}\right)$

\begin{tabular}{lllllll}
\hline & $U^{11}$ & $U^{22}$ & $U^{33}$ & $U^{12}$ & $U^{13}$ & $U^{23}$ \\
\hline O31 & $0.0180(10)$ & $0.0128(9)$ & $0.0356(12)$ & $0.0031(8)$ & $-0.0017(9)$ & $-0.0058(9)$ \\
N1 & $0.0155(12)$ & $0.0137(11)$ & $0.0229(13)$ & $-0.0001(10)$ & $0.0022(11)$ & $-0.0008(10)$ \\
N32 & $0.0136(12)$ & $0.0114(11)$ & $0.0236(13)$ & $0.0014(10)$ & $-0.0003(10)$ & $-0.0012(10)$ \\
N41 & $0.0152(13)$ & $0.0120(12)$ & $0.0314(14)$ & $0.0002(10)$ & $-0.0025(12)$ & $-0.0058(10)$ \\
C2 & $0.0173(14)$ & $0.0107(13)$ & $0.0202(15)$ & $-0.0031(12)$ & $0.0028(12)$ & $-0.0018(11)$ \\
C3 & $0.0133(14)$ & $0.0137(13)$ & $0.0194(14)$ & $-0.0012(12)$ & $0.0052(12)$ & $-0.0011(11)$ \\
C4 & $0.0152(14)$ & $0.0139(13)$ & $0.0184(15)$ & $-0.0010(11)$ & $0.0042(12)$ & $-0.0010(11)$ \\
C5 & $0.0203(15)$ & $0.0159(14)$ & $0.0226(15)$ & $-0.0033(13)$ & $0.0013(13)$ & $-0.0032(12)$ \\
C4A & $0.0146(14)$ & $0.0146(14)$ & $0.0193(14)$ & $-0.0032(12)$ & $0.0040(12)$ & $0.0013(11)$ \\
C6 & $0.0273(17)$ & $0.0212(15)$ & $0.0224(15)$ & $-0.0067(14)$ & $-0.0068(14)$ & $-0.0013(12)$ \\
C7 & $0.0203(16)$ & $0.0232(16)$ & $0.0287(17)$ & $-0.0014(13)$ & $-0.0065(13)$ & $0.0028(13)$ \\
C8 & $0.0195(15)$ & $0.0171(14)$ & $0.0260(16)$ & $0.0008(13)$ & $0.0010(13)$ & $0.0024(12)$ \\
C8A & $0.0164(14)$ & $0.0138(13)$ & $0.0179(14)$ & $-0.0031(12)$ & $0.0048(12)$ & $-0.0003(11)$ \\
C31 & $0.0145(14)$ & $0.0123(12)$ & $0.0208(15)$ & $-0.0020(12)$ & $0.0057(12)$ & $0.0000(12)$ \\
C321 & $0.0136(14)$ & $0.0103(13)$ & $0.0200(14)$ & $-0.0020(11)$ & $0.0009(12)$ & $0.0035(11)$ \\
C322 & $0.0163(14)$ & $0.0118(13)$ & $0.0238(16)$ & $-0.0002(12)$ & $0.0036(12)$ & $0.0004(11)$ \\
C323 & $0.0171(14)$ & $0.0180(14)$ & $0.0202(15)$ & $-0.0030(13)$ & $0.0036(12)$ & $0.0041(11)$ \\
C324 & $0.0159(15)$ & $0.0152(14)$ & $0.0232(15)$ & $-0.0035(12)$ & $0.0031(12)$ & $0.0057(12)$ \\
C325 & $0.0138(14)$ & $0.0168(14)$ & $0.0267(16)$ & $0.0018(12)$ & $0.0048(12)$ & $0.0032(12)$ \\
C326 & $0.0151(14)$ & $0.0148(13)$ & $0.0205(15)$ & $-0.0018(11)$ & $0.0034(12)$ & $-0.0011(12)$ \\
C327 & $0.0246(16)$ & $0.0234(16)$ & $0.0269(17)$ & $0.0001(14)$ & $0.0022(14)$ & $-0.0033(13)$ \\
C328 & $0.0186(16)$ & $0.0316(17)$ & $0.0261(16)$ & $-0.0015(14)$ & $0.0003(13)$ & $0.0025(13)$
\end{tabular}




\begin{tabular}{lllllll} 
C411 & $0.0241(16)$ & $0.0132(13)$ & $0.0208(15)$ & $-0.0013(12)$ & $-0.0066(13)$ & $-0.0002(12)$ \\
C412 & $0.0225(16)$ & $0.0174(14)$ & $0.0209(16)$ & $0.0005(13)$ & $-0.0013(13)$ & $0.0001(12)$ \\
C413 & $0.0279(17)$ & $0.0128(14)$ & $0.0171(15)$ & $0.0022(12)$ & $-0.0057(13)$ & $-0.0007(11)$ \\
C414 & $0.0223(16)$ & $0.0205(15)$ & $0.0197(16)$ & $-0.0021(12)$ & $-0.0065(13)$ & $0.0028(12)$ \\
C415 & $0.0198(15)$ & $0.0252(16)$ & $0.0235(16)$ & $-0.0019(13)$ & $-0.0022(13)$ & $0.0035(12)$ \\
C416 & $0.0206(15)$ & $0.0150(14)$ & $0.0245(16)$ & $0.0005(12)$ & $-0.0025(13)$ & $-0.0018(12)$ \\
C417 & $0.0307(17)$ & $0.0171(15)$ & $0.0347(18)$ & $-0.0001(14)$ & $0.0016(15)$ & $-0.0046(13)$ \\
C418 & $0.0298(18)$ & $0.0213(16)$ & $0.0333(18)$ & $-0.0062(14)$ & $-0.0042(15)$ & $0.0036(13)$ \\
\hline
\end{tabular}

Geometric parameters $\left(\AA,{ }^{\circ}\right)$

\begin{tabular}{|c|c|c|c|}
\hline $\mathrm{O} 31-\mathrm{C} 31$ & $1.238(3)$ & $\mathrm{C} 323-\mathrm{C} 327$ & $1.505(4)$ \\
\hline $\mathrm{N} 1-\mathrm{C} 2$ & $1.315(4)$ & $\mathrm{C} 324-\mathrm{C} 325$ & $1.386(4)$ \\
\hline $\mathrm{N} 1-\mathrm{C} 8 \mathrm{~A}$ & $1.367(4)$ & C324-C328 & $1.505(4)$ \\
\hline $\mathrm{N} 32-\mathrm{C} 31$ & $1.350(3)$ & $\mathrm{C} 325-\mathrm{C} 326$ & $1.384(4)$ \\
\hline $\mathrm{N} 32-\mathrm{C} 321$ & $1.416(4)$ & $\mathrm{C} 325-\mathrm{H} 325$ & 0.9500 \\
\hline N32-H32 & $0.90(4)$ & $\mathrm{C} 326-\mathrm{H} 326$ & 0.9500 \\
\hline $\mathrm{N} 41-\mathrm{C} 4$ & $1.364(3)$ & C327-H32A & 0.9800 \\
\hline $\mathrm{N} 41-\mathrm{C} 411$ & $1.437(4)$ & С $327-\mathrm{H} 32 \mathrm{~B}$ & 0.9800 \\
\hline N41-H41 & $0.84(4)$ & $\mathrm{C} 327-\mathrm{H} 32 \mathrm{C}$ & 0.9800 \\
\hline $\mathrm{C} 2-\mathrm{C} 3$ & $1.416(4)$ & C328-H32D & 0.9800 \\
\hline $\mathrm{C} 2-\mathrm{H} 2$ & $0.96(3)$ & C328-H32E & 0.9800 \\
\hline $\mathrm{C} 3-\mathrm{C} 4$ & $1.405(4)$ & $\mathrm{C} 328-\mathrm{H} 32 \mathrm{~F}$ & 0.9800 \\
\hline $\mathrm{C} 3-\mathrm{C} 31$ & $1.494(4)$ & $\mathrm{C} 411-\mathrm{C} 412$ & $1.379(4)$ \\
\hline $\mathrm{C} 4-\mathrm{C} 4 \mathrm{~A}$ & $1.449(4)$ & $\mathrm{C} 411-\mathrm{C} 416$ & $1.389(4)$ \\
\hline $\mathrm{C} 5-\mathrm{C} 6$ & $1.367(4)$ & $\mathrm{C} 412-\mathrm{C} 413$ & $1.408(4)$ \\
\hline $\mathrm{C} 5-\mathrm{C} 4 \mathrm{~A}$ & $1.413(4)$ & $\mathrm{C} 412-\mathrm{H} 412$ & 0.9500 \\
\hline $\mathrm{C} 5-\mathrm{H} 5$ & 0.9500 & $\mathrm{C} 413-\mathrm{C} 414$ & $1.392(4)$ \\
\hline $\mathrm{C} 4 \mathrm{~A}-\mathrm{C} 8 \mathrm{~A}$ & $1.411(4)$ & $\mathrm{C} 413-\mathrm{C} 417$ & $1.503(4)$ \\
\hline $\mathrm{C} 6-\mathrm{C} 7$ & $1.401(4)$ & C414-C415 & $1.377(4)$ \\
\hline $\mathrm{C} 6-\mathrm{H} 6$ & 0.9500 & $\mathrm{C} 414-\mathrm{C} 418$ & $1.514(4)$ \\
\hline $\mathrm{C} 7-\mathrm{C} 8$ & $1.365(4)$ & $\mathrm{C} 415-\mathrm{C} 416$ & $1.390(4)$ \\
\hline $\mathrm{C} 7-\mathrm{H} 7$ & 0.9500 & $\mathrm{C} 415-\mathrm{H} 415$ & 0.9500 \\
\hline $\mathrm{C} 8-\mathrm{C} 8 \mathrm{~A}$ & $1.417(4)$ & $\mathrm{C} 416-\mathrm{H} 416$ & 0.9500 \\
\hline $\mathrm{C} 8-\mathrm{H} 8$ & 0.9500 & $\mathrm{C} 417-\mathrm{H} 41 \mathrm{D}$ & 0.9800 \\
\hline C321-C322 & $1.391(4)$ & $\mathrm{C} 417-\mathrm{H} 41 \mathrm{E}$ & 0.9800 \\
\hline C321-C326 & $1.391(4)$ & $\mathrm{C} 417-\mathrm{H} 41 \mathrm{~F}$ & 0.9800 \\
\hline C $322-\mathrm{C} 323$ & $1.387(4)$ & $\mathrm{C} 418-\mathrm{H} 41 \mathrm{~A}$ & 0.9800 \\
\hline C322-H322 & 0.9500 & $\mathrm{C} 418-\mathrm{H} 41 \mathrm{~B}$ & 0.9800 \\
\hline C $323-\mathrm{C} 324$ & $1.410(4)$ & $\mathrm{C} 418-\mathrm{H} 41 \mathrm{C}$ & 0.9800 \\
\hline $\mathrm{C} 2-\mathrm{N} 1-\mathrm{C} 8 \mathrm{~A}$ & $117.2(2)$ & $\mathrm{C} 326-\mathrm{C} 325-\mathrm{C} 324$ & $122.7(3)$ \\
\hline $\mathrm{C} 31-\mathrm{N} 32-\mathrm{C} 321$ & $126.6(2)$ & $\mathrm{C} 326-\mathrm{C} 325-\mathrm{H} 325$ & 118.7 \\
\hline $\mathrm{C} 31-\mathrm{N} 32-\mathrm{H} 32$ & $119(2)$ & $\mathrm{C} 324-\mathrm{C} 325-\mathrm{H} 325$ & 118.7 \\
\hline $\mathrm{C} 321-\mathrm{N} 32-\mathrm{H} 32$ & $114(2)$ & $\mathrm{C} 325-\mathrm{C} 326-\mathrm{C} 321$ & $119.2(3)$ \\
\hline $\mathrm{C} 4-\mathrm{N} 41-\mathrm{C} 411$ & $125.7(2)$ & $\mathrm{C} 325-\mathrm{C} 326-\mathrm{H} 326$ & 120.4 \\
\hline $\mathrm{C} 4-\mathrm{N} 41-\mathrm{H} 41$ & $112(2)$ & $\mathrm{C} 321-\mathrm{C} 326-\mathrm{H} 326$ & 120.4 \\
\hline C411-N41-H41 & $115(2)$ & C $323-\mathrm{C} 327-\mathrm{H} 32 \mathrm{~A}$ & 109.5 \\
\hline
\end{tabular}




\begin{tabular}{|c|c|c|c|}
\hline $\mathrm{N} 1-\mathrm{C} 2-\mathrm{C} 3$ & $125.9(3)$ & C $323-\mathrm{C} 327-\mathrm{H} 32 \mathrm{~B}$ & 109.5 \\
\hline $\mathrm{N} 1-\mathrm{C} 2-\mathrm{H} 2$ & $111.9(17)$ & $\mathrm{H} 32 \mathrm{~A}-\mathrm{C} 327-\mathrm{H} 32 \mathrm{~B}$ & 109.5 \\
\hline $\mathrm{C} 3-\mathrm{C} 2-\mathrm{H} 2$ & $122.2(17)$ & $\mathrm{C} 323-\mathrm{C} 327-\mathrm{H} 32 \mathrm{C}$ & 109.5 \\
\hline $\mathrm{C} 4-\mathrm{C} 3-\mathrm{C} 2$ & $117.6(3)$ & $\mathrm{H} 32 \mathrm{~A}-\mathrm{C} 327-\mathrm{H} 32 \mathrm{C}$ & 109.5 \\
\hline $\mathrm{C} 4-\mathrm{C} 3-\mathrm{C} 31$ & $121.3(2)$ & $\mathrm{H} 32 \mathrm{~B}-\mathrm{C} 327-\mathrm{H} 32 \mathrm{C}$ & 109.5 \\
\hline $\mathrm{C} 2-\mathrm{C} 3-\mathrm{C} 31$ & $120.9(2)$ & $\mathrm{C} 324-\mathrm{C} 328-\mathrm{H} 32 \mathrm{D}$ & 109.5 \\
\hline $\mathrm{N} 41-\mathrm{C} 4-\mathrm{C} 3$ & $121.9(3)$ & C324-C328-H32E & 109.5 \\
\hline $\mathrm{N} 41-\mathrm{C} 4-\mathrm{C} 4 \mathrm{~A}$ & $120.6(2)$ & $\mathrm{H} 32 \mathrm{D}-\mathrm{C} 328-\mathrm{H} 32 \mathrm{E}$ & 109.5 \\
\hline $\mathrm{C} 3-\mathrm{C} 4-\mathrm{C} 4 \mathrm{~A}$ & $117.4(2)$ & $\mathrm{C} 324-\mathrm{C} 328-\mathrm{H} 32 \mathrm{~F}$ & 109.5 \\
\hline $\mathrm{C} 6-\mathrm{C} 5-\mathrm{C} 4 \mathrm{~A}$ & $120.9(3)$ & $\mathrm{H} 32 \mathrm{D}-\mathrm{C} 328-\mathrm{H} 32 \mathrm{~F}$ & 109.5 \\
\hline $\mathrm{C} 6-\mathrm{C} 5-\mathrm{H} 5$ & 119.5 & $\mathrm{H} 32 \mathrm{E}-\mathrm{C} 328-\mathrm{H} 32 \mathrm{~F}$ & 109.5 \\
\hline $\mathrm{C} 4 \mathrm{~A}-\mathrm{C} 5-\mathrm{H} 5$ & 119.5 & $\mathrm{C} 412-\mathrm{C} 411-\mathrm{C} 416$ & $119.5(3)$ \\
\hline $\mathrm{C} 8 \mathrm{~A}-\mathrm{C} 4 \mathrm{~A}-\mathrm{C} 5$ & 118.3 & $\mathrm{C} 412-\mathrm{C} 411-\mathrm{N} 41$ & $119.0(3)$ \\
\hline $\mathrm{C} 8 \mathrm{~A}-\mathrm{C} 4 \mathrm{~A}-\mathrm{C} 4$ & $118.3(2)$ & $\mathrm{C} 416-\mathrm{C} 411-\mathrm{N} 41$ & $121.5(2)$ \\
\hline $\mathrm{C} 5-\mathrm{C} 4 \mathrm{~A}-\mathrm{C} 4$ & $123.3(3)$ & $\mathrm{C} 411-\mathrm{C} 412-\mathrm{C} 413$ & $121.2(3)$ \\
\hline $\mathrm{C} 5-\mathrm{C} 6-\mathrm{C} 7$ & $120.4(3)$ & $\mathrm{C} 411-\mathrm{C} 412-\mathrm{H} 412$ & 119.4 \\
\hline $\mathrm{C} 5-\mathrm{C} 6-\mathrm{H} 6$ & 119.8 & $\mathrm{C} 413-\mathrm{C} 412-\mathrm{H} 412$ & 119.4 \\
\hline $\mathrm{C} 7-\mathrm{C} 6-\mathrm{H} 6$ & 119.8 & $\mathrm{C} 414-\mathrm{C} 413-\mathrm{C} 412$ & $118.8(3)$ \\
\hline $\mathrm{C} 8-\mathrm{C} 7-\mathrm{C} 6$ & $120.3(3)$ & $\mathrm{C} 414-\mathrm{C} 413-\mathrm{C} 417$ & $121.4(3)$ \\
\hline $\mathrm{C} 8-\mathrm{C} 7-\mathrm{H} 7$ & 119.9 & $\mathrm{C} 412-\mathrm{C} 413-\mathrm{C} 417$ & $119.8(3)$ \\
\hline $\mathrm{C} 6-\mathrm{C} 7-\mathrm{H} 7$ & 119.9 & $\mathrm{C} 415-\mathrm{C} 414-\mathrm{C} 413$ & $119.6(3)$ \\
\hline $\mathrm{C} 7-\mathrm{C} 8-\mathrm{C} 8 \mathrm{~A}$ & $120.3(3)$ & $\mathrm{C} 415-\mathrm{C} 414-\mathrm{C} 418$ & $120.7(3)$ \\
\hline $\mathrm{C} 7-\mathrm{C} 8-\mathrm{H} 8$ & 119.9 & $\mathrm{C} 413-\mathrm{C} 414-\mathrm{C} 418$ & $119.6(3)$ \\
\hline $\mathrm{C} 8 \mathrm{~A}-\mathrm{C} 8-\mathrm{H} 8$ & 119.9 & $\mathrm{C} 414-\mathrm{C} 415-\mathrm{C} 416$ & $121.5(3)$ \\
\hline $\mathrm{N} 1-\mathrm{C} 8 \mathrm{~A}-\mathrm{C} 4 \mathrm{~A}$ & $122.8(3)$ & $\mathrm{C} 414-\mathrm{C} 415-\mathrm{H} 415$ & 119.3 \\
\hline $\mathrm{N} 1-\mathrm{C} 8 \mathrm{~A}-\mathrm{C} 8$ & $117.7(3)$ & $\mathrm{C} 416-\mathrm{C} 415-\mathrm{H} 415$ & 119.3 \\
\hline $\mathrm{C} 4 \mathrm{~A}-\mathrm{C} 8 \mathrm{~A}-\mathrm{C} 8$ & $119.5(3)$ & $\mathrm{C} 411-\mathrm{C} 416-\mathrm{C} 415$ & $119.4(3)$ \\
\hline $\mathrm{O} 31-\mathrm{C} 31-\mathrm{N} 32$ & $121.4(3)$ & $\mathrm{C} 411-\mathrm{C} 416-\mathrm{H} 416$ & 120.3 \\
\hline $\mathrm{O} 31-\mathrm{C} 31-\mathrm{C} 3$ & $121.1(2)$ & $\mathrm{C} 415-\mathrm{C} 416-\mathrm{H} 416$ & 120.3 \\
\hline $\mathrm{N} 32-\mathrm{C} 31-\mathrm{C} 3$ & $117.4(2)$ & C413-C417-H41D & 109.5 \\
\hline $\mathrm{C} 322-\mathrm{C} 321-\mathrm{C} 326$ & $118.8(3)$ & $\mathrm{C} 413-\mathrm{C} 417-\mathrm{H} 41 \mathrm{E}$ & 109.5 \\
\hline $\mathrm{C} 322-\mathrm{C} 321-\mathrm{N} 32$ & $116.8(2)$ & $\mathrm{H} 41 \mathrm{D}-\mathrm{C} 417-\mathrm{H} 41 \mathrm{E}$ & 109.5 \\
\hline $\mathrm{C} 326-\mathrm{C} 321-\mathrm{N} 32$ & $124.3(2)$ & $\mathrm{C} 413-\mathrm{C} 417-\mathrm{H} 41 \mathrm{~F}$ & 109.5 \\
\hline $\mathrm{C} 323-\mathrm{C} 322-\mathrm{C} 321$ & $122.1(3)$ & $\mathrm{H} 41 \mathrm{D}-\mathrm{C} 417-\mathrm{H} 41 \mathrm{~F}$ & 109.5 \\
\hline C323-C322-H322 & 119.0 & $\mathrm{H} 41 \mathrm{E}-\mathrm{C} 417-\mathrm{H} 41 \mathrm{~F}$ & 109.5 \\
\hline C321-C322-H322 & 119.0 & $\mathrm{C} 414-\mathrm{C} 418-\mathrm{H} 41 \mathrm{~A}$ & 109.5 \\
\hline $\mathrm{C} 322-\mathrm{C} 323-\mathrm{C} 324$ & $119.1(3)$ & $\mathrm{C} 414-\mathrm{C} 418-\mathrm{H} 41 \mathrm{~B}$ & 109.5 \\
\hline $\mathrm{C} 322-\mathrm{C} 323-\mathrm{C} 327$ & $120.1(3)$ & $\mathrm{H} 41 \mathrm{~A}-\mathrm{C} 418-\mathrm{H} 41 \mathrm{~B}$ & 109.5 \\
\hline $\mathrm{C} 324-\mathrm{C} 323-\mathrm{C} 327$ & $120.8(3)$ & $\mathrm{C} 414-\mathrm{C} 418-\mathrm{H} 41 \mathrm{C}$ & 109.5 \\
\hline C $325-\mathrm{C} 324-\mathrm{C} 323$ & $118.1(3)$ & $\mathrm{H} 41 \mathrm{~A}-\mathrm{C} 418-\mathrm{H} 41 \mathrm{C}$ & 109.5 \\
\hline $\mathrm{C} 325-\mathrm{C} 324-\mathrm{C} 328$ & $120.7(3)$ & $\mathrm{H} 41 \mathrm{~B}-\mathrm{C} 418-\mathrm{H} 41 \mathrm{C}$ & 109.5 \\
\hline $\mathrm{C} 323-\mathrm{C} 324-\mathrm{C} 328$ & $121.2(3)$ & & \\
\hline $\mathrm{C} 8 \mathrm{~A}-\mathrm{N} 1-\mathrm{C} 2-\mathrm{C} 3$ & $-5.5(4)$ & $\mathrm{C} 2-\mathrm{C} 3-\mathrm{C} 31-\mathrm{N} 32$ & $5.0(4)$ \\
\hline $\mathrm{N} 1-\mathrm{C} 2-\mathrm{C} 3-\mathrm{C} 4$ & $1.1(4)$ & $\mathrm{C} 31-\mathrm{N} 32-\mathrm{C} 321-\mathrm{C} 322$ & $-150.3(3)$ \\
\hline $\mathrm{N} 1-\mathrm{C} 2-\mathrm{C} 3-\mathrm{C} 31$ & $-174.0(3)$ & $\mathrm{C} 31-\mathrm{N} 32-\mathrm{C} 321-\mathrm{C} 326$ & $31.7(4)$ \\
\hline $\mathrm{C} 411-\mathrm{N} 41-\mathrm{C} 4-\mathrm{C} 3$ & $141.0(3)$ & $\mathrm{C} 326-\mathrm{C} 321-\mathrm{C} 322-\mathrm{C} 323$ & $0.2(4)$ \\
\hline $\mathrm{C} 411-\mathrm{N} 41-\mathrm{C} 4-\mathrm{C} 4 \mathrm{~A}$ & $-41.6(4)$ & $\mathrm{N} 32-\mathrm{C} 321-\mathrm{C} 322-\mathrm{C} 323$ & $-177.9(2)$ \\
\hline
\end{tabular}




$\begin{array}{llll}\mathrm{C} 2-\mathrm{C} 3-\mathrm{C} 4-\mathrm{N} 41 & -175.7(3) & \mathrm{C} 321-\mathrm{C} 322-\mathrm{C} 323-\mathrm{C} 324 & 0.8(4) \\ \mathrm{C} 31-\mathrm{C} 3-\mathrm{C} 4-\mathrm{N} 41 & -0.6(4) & \mathrm{C} 321-\mathrm{C} 322-\mathrm{C} 323-\mathrm{C} 327 & -178.3(3) \\ \mathrm{C} 2-\mathrm{C} 3-\mathrm{C} 4-\mathrm{C} 4 \mathrm{~A} & 6.8(4) & \mathrm{C} 322-\mathrm{C} 323-\mathrm{C} 324-\mathrm{C} 325 & -0.9(4) \\ \mathrm{C} 31-\mathrm{C} 3-\mathrm{C} 4-\mathrm{C} 4 \mathrm{~A} & -178.1(2) & \mathrm{C} 327-\mathrm{C} 323-\mathrm{C} 324-\mathrm{C} 325 & 178.1(3) \\ \mathrm{C} 6-\mathrm{C} 5-\mathrm{C} 4 \mathrm{~A}-\mathrm{C} 8 \mathrm{~A} & -4.1(4) & \mathrm{C} 322-\mathrm{C} 323-\mathrm{C} 324-\mathrm{C} 328 & 179.8(3) \\ \mathrm{C} 6-\mathrm{C} 5-\mathrm{C} 4 \mathrm{~A}-\mathrm{C} 4 & 179.2(3) & \mathrm{C} 327-\mathrm{C} 323-\mathrm{C} 324-\mathrm{C} 328 & -1.2(4) \\ \mathrm{N} 41-\mathrm{C} 4-\mathrm{C} 4 \mathrm{~A}-\mathrm{C} 8 \mathrm{~A} & 172.4(3) & \mathrm{C} 323-\mathrm{C} 324-\mathrm{C} 325-\mathrm{C} 326 & 0.1(4) \\ \mathrm{C} 3-\mathrm{C} 4-\mathrm{C} 4 \mathrm{~A}-\mathrm{C} 8 \mathrm{~A} & -10.1(4) & \mathrm{C} 328-\mathrm{C} 324-\mathrm{C} 325-\mathrm{C} 326 & 179.4(3) \\ \mathrm{N} 41-\mathrm{C} 4-\mathrm{C} 4 \mathrm{~A}-\mathrm{C} 5 & -10.8(4) & \mathrm{C} 324-\mathrm{C} 325-\mathrm{C} 326-\mathrm{C} 321 & 0.8(4) \\ \mathrm{C} 3-\mathrm{C} 4-\mathrm{C} 4 \mathrm{~A}-\mathrm{C} 5 & 166.7(3) & \mathrm{C} 322-\mathrm{C} 321-\mathrm{C} 326-\mathrm{C} 325 & -1.0(4) \\ \mathrm{C} 4 \mathrm{~A}-\mathrm{C} 5-\mathrm{C} 6-\mathrm{C} 7 & -1.5(4) & \mathrm{N} 32-\mathrm{C} 321-\mathrm{C} 326-\mathrm{C} 325 & 176.9(2) \\ \mathrm{C} 5-\mathrm{C} 6-\mathrm{C} 7-\mathrm{C} 8 & 4.7(5) & \mathrm{C} 4-\mathrm{N} 41-\mathrm{C} 411-\mathrm{C} 412 & 155.0(3) \\ \mathrm{C} 6-\mathrm{C} 7-\mathrm{C} 8-\mathrm{C} 8 \mathrm{~A} & -2.2(4) & \mathrm{C} 4-\mathrm{N} 41-\mathrm{C} 411-\mathrm{C} 416 & -27.8(4) \\ \mathrm{C} 2-\mathrm{N} 1-\mathrm{C} 8 \mathrm{~A}-\mathrm{C} 4 \mathrm{~A} & 1.7(4) & \mathrm{C} 416-\mathrm{C} 411-\mathrm{C} 412-\mathrm{C} 413 & 2.3(4) \\ \mathrm{C} 2-\mathrm{N} 1-\mathrm{C} 8 \mathrm{~A}-\mathrm{C} 8 & -175.7(2) & \mathrm{N} 41-\mathrm{C} 411-\mathrm{C} 412-\mathrm{C} 413 & 179.6(3) \\ \mathrm{C} 5-\mathrm{C} 4 \mathrm{~A}-\mathrm{C} 8 \mathrm{~A}-\mathrm{N} 1 & -170.9(3) & \mathrm{C} 411-\mathrm{C} 412-\mathrm{C} 413-\mathrm{C} 414 & -1.1(4) \\ \mathrm{C} 4-\mathrm{C} 4 \mathrm{~A}-\mathrm{C} 8 \mathrm{~A}-\mathrm{N} 1 & 6.0(4) & \mathrm{C} 411-\mathrm{C} 412-\mathrm{C} 413-\mathrm{C} 417 & 178.3(3) \\ \mathrm{C} 5-\mathrm{C} 4 \mathrm{~A}-\mathrm{C} 8 \mathrm{~A}-\mathrm{C} 8 & 6.4(4) & \mathrm{C} 412-\mathrm{C} 413-\mathrm{C} 414-\mathrm{C} 415 & -0.5(4) \\ \mathrm{C} 4-\mathrm{C} 4 \mathrm{~A}-\mathrm{C} 8 \mathrm{~A}-\mathrm{C} 8 & -176.7(2) & \mathrm{C} 417-\mathrm{C} 413-\mathrm{C} 414-\mathrm{C} 415 & -179.9(3) \\ \mathrm{C} 7-\mathrm{C} 8-\mathrm{C} 8 \mathrm{~A}-\mathrm{N} 1 & 174.1(3) & \mathrm{C} 412-\mathrm{C} 413-\mathrm{C} 414-\mathrm{C} 418 & 178.7(3) \\ \mathrm{C} 7-\mathrm{C} 8-\mathrm{C} 8 \mathrm{~A}-\mathrm{C} 4 \mathrm{~A} & -3.4(4) & \mathrm{C} 417-\mathrm{C} 413-\mathrm{C} 414-\mathrm{C} 418 & -0.6(4) \\ \mathrm{C} 321-\mathrm{N} 32-\mathrm{C} 31-\mathrm{O} 31 & -3.1(4) & \mathrm{C} 413-\mathrm{C} 414-\mathrm{C} 415-\mathrm{C} 416 & 1.0(4) \\ \mathrm{C} 321-\mathrm{N} 32-\mathrm{C} 31-\mathrm{C} 3 & 173.8(2) & \mathrm{C} 418-\mathrm{C} 414-\mathrm{C} 415-\mathrm{C} 416 & -178.3(3) \\ \mathrm{C} 4-\mathrm{C} 3-\mathrm{C} 31-\mathrm{O} 31 & 6.9(4) & \mathrm{C} 412-\mathrm{C} 411-\mathrm{C} 416-\mathrm{C} 415 & -1.8(4) \\ \mathrm{C} 2-\mathrm{C} 3-\mathrm{C} 31-\mathrm{O} 31 & -178.1(3) & \mathrm{N} 41-\mathrm{C} 411-\mathrm{C} 416-\mathrm{C} 415 & -179.1(3) \\ \mathrm{C} 4-\mathrm{C} 3-\mathrm{C} 31-\mathrm{N} 32 & -170.0(3) & \mathrm{C} 414-\mathrm{C} 415-\mathrm{C} 416-\mathrm{C} 411 & 0.2(4) \\ & & & \end{array}$

Hydrogen-bond geometry $\left(A,{ }^{\circ}\right)$

$\mathrm{Cg}$ is the centroid of the $\mathrm{N} 1 / \mathrm{C} 2-\mathrm{C} 4 / \mathrm{C} 4 A / \mathrm{C} 8 A$ ring.

\begin{tabular}{lllll}
\hline$D-\mathrm{H} \cdots A$ & $D-\mathrm{H}$ & $\mathrm{H} \cdots A$ & $D \cdots A$ & $D-\mathrm{H} \cdots A$ \\
\hline $\mathrm{N} 41-\mathrm{H} 41 \cdots \mathrm{O} 31$ & $0.84(4)$ & $1.93(3)$ & $2.635(3)$ & $142(3)$ \\
$\mathrm{C} 326-\mathrm{H} 326 \cdots \mathrm{O} 31$ & 0.95 & 2.40 & $2.887(3)$ & 112 \\
$\mathrm{~N} 32-\mathrm{H} 32 \cdots \mathrm{N} 11^{\mathrm{i}}$ & $0.90(4)$ & $2.07(4)$ & $2.891(3)$ & $150(3)$ \\
$\mathrm{C} 2-\mathrm{H} 2 \cdots \mathrm{N} 1^{\mathrm{i}}$ & $0.96(3)$ & $2.55(3)$ & $3.477(4)$ & $163(2)$ \\
$\mathrm{C} 416-\mathrm{H} 416 \cdots \mathrm{O} 31^{\mathrm{ii}}$ & 0.95 & 2.39 & $3.252(4)$ & 150 \\
$\mathrm{C} 326-\mathrm{H} 326 \cdots \mathrm{Cg}^{\mathrm{iii}}$ & 0.95 & 2.82 & $3.398(3)$ & 120 \\
\hline
\end{tabular}

Symmetry codes: (i) $x+1 / 2,-y+3 / 2,-z+1$; (ii) $x-1, y, z$; (iii) $x+1, y, z$. 